\title{
Regional-scale analysis of high-mountain multi-hazard and risk indicators in the Pamir (Tajikistan) with GRASS GIS
}

\author{
F. E. Gruber ${ }^{1}$ and M. Mergili ${ }^{2}$ \\ ${ }^{1}$ Institute of Geography, University of Innsbruck, Innrain 52, 6020 Innsbruck, Austria \\ ${ }^{2}$ Institute of Applied Geology, University of Natural Resources and Life Sciences (BOKU), Vienna, Peter-Jordan-Straße 70, \\ 1190 Vienna, Austria
}

Correspondence to: M. Mergili (martin.mergili@boku.ac.at)

Received: 11 April 2013 - Published in Nat. Hazards Earth Syst. Sci. Discuss.: 26 April 2013

Revised: 24 September 2013 - Accepted: 8 October 2013 - Published: 7 November 2013

\begin{abstract}
We present a model framework for the regionalscale analysis of high-mountain multi-hazard and -risk indicators, implemented with the open-source software package GRASS GIS. This framework is applied to a $98300 \mathrm{~km}^{2}$ study area centred in the Pamir (Tajikistan). It includes (i) rock slides, (ii) ice avalanches, (iii) periglacial debris flows and (iv) lake outburst floods. First, a hazard indicator is assigned to each relevant object (steep rock face, glacier or periglacial slope, lake). This indicator depends on the susceptibility and on the possible event magnitude. Second, the possible travel distances, impact areas and, consequently, impact hazard indicators for all types of processes are computed using empirical relationships. The impact hazard indicators are finally superimposed with an exposure indicator derived from the type of land use, resulting in a raster map of risk indicators finally discretized at the community level. The analysis results are presented and discussed at different spatial scales. The major outcome of the study, a set of comprehensive regional-scale hazard and risk indication maps, shall represent an objective basis for the prioritization of target communities for further research and risk mitigation measures.
\end{abstract}

\section{Introduction}

High-mountain areas are commonly experiencing pronounced environmental changes such as permafrost melting and the retreat of glaciers, caused by atmospheric temperature increase (Beniston, 2003; Huber et al., 2005; IPCC, 2007; WGMS, 2008; Harris et al., 2009). Together with earthquakes or volcanic eruptions, they disturb the dynamic equilibrium of the fragile high-mountain geomorphic systems, leading to an increased occurrence of rapid mass movements (Evans and Clague, 1994; Huggel et al., 2004a, b; Kääb et al., 2005; IPCC, 2007; Quincey et al., 2007; Harris et al., 2009; Dussaillant et al., 2010; Haeberli et al., 2010a).

Whilst such mass movements often occur in remote areas and remain unrecognized, they may also evolve into long-distance flows or avalanches affecting the communities in the valleys. Such processes are referred to as remote geohazards. They are commonly related to the massive entrainment of loose material or the interaction of two or more process types (process chain). Several cases are evident where slope failures including rock and/or ice have converted into long-distance avalanches and consecutive processes. A striking example is the 1970 Huascarán event (Cordillera Blanca, Peru) where several thousand people lost their lives in the town of Yungay (Evans et al., 2009a). On 20 September 2002, a rock-ice avalanche in the Russian Caucasus entrained a glacier. The resulting flow continued for $20 \mathrm{~km}$ as an avalanche of ice, rock and debris and a further $15 \mathrm{~km}$ as mud flow, resulting in about 140 fatalities (Kolka/Karmadon event; Huggel et al., 2005). On 11 April 2010, an ice avalanche from far upslope rushed into Laguna (Lake) 513 in the Cordillera Blanca, causing a destructive outburst flood (Haeberli et al., 2010b).

Lakes are commonly involved in remote geohazard processes (Costa, 1985; Evans, 1986; Costa and Schuster, 1988; Walder and Costa, 1996; Walder and O'Connor, 1997). Landslide-dammed lakes are of particular interest as most of them drain within the first year after their formation (Costa and Schuster, 1988) whilst others persist for centuries. Glacial lakes, impounded by ice (Tweed and Russell, 1999) or (often ice-cored) moraines, are commonly coupled to 
retreating or surging glaciers and therefore highly dynamic. Such lakes often occur in areas influenced by permafrost. Some lakes are prone to sudden drainage (glacial lake outburst floods or GLOFs). Studies of this phenomenon cover most glacierized mountain areas in the world such as the Himalayas (Watanabe and Rothacher, 1996; Richardson and Reynolds, 2000; ICIMOD, 2011), the Karakorum (Hewitt, 1982; Hewitt and Liu, 2010), the Pamir (Mergili and Schneider, 2011), the Tien Shan (Narama et al., 2010; Bolch et al., 2011), the Andes (Vilímek et al., 2005; Harrison et al., 2006; Haeberli et al., 2010b), the North American mountains (Clarke, 1982), the Norwegian mountains (Breien et al., 2008) and the western Alps (Haeberli, 1983; Tinti et al., 1999; Huggel et al., 2002, 2003). GLOFs can evolve in different ways, for example by mass movements into lakes, rising lake levels leading to overflow, progressive incision, mechanical rupture or retrogressive erosion of a dam, hydrostatic failure or degradation of glacier dams or ice cores in moraine dams (Walder and Costa, 1996; Richardson and Reynolds, 2000). Peak discharges are often of some magnitudes higher than in the case of ordinary floods (Cenderelli and Wohl, 2001). Entrainment may considerably increase the event magnitude and convert the flood into a destructive debris flow.

A common feature of long-distance rock mass movements, ice avalanches, debris flows, lake outburst floods and related process chains is their occurrence as rare (low frequency) or singular events. The location, timing, magnitude and impact area of remote geohazard events are often hard or even impossible to predict, even though the governing processes are fairly well understood and specific events were successfully back-calculated with deterministic computer models (Evans et al., 2009a, b). This is particularly true where multiple hazards are evident over a large area and/or where the resources for a broad-scale continuous monitoring of potentially hazardous situations are lacking, i.e. in developing countries. Here it is essential to identify possible source and - particularly - impact areas of remote geohazard processes at the broad (regional) scale in order to prioritize target areas for risk mitigation measures. Huggel et al. (2003, 2004a, b) and Mergili and Schneider (2011) have presented computer models suitable for the regional-scale analysis of highmountain hazards such as GLOFs, periglacial debris flows or ice avalanches. Some of these models include process interactions. However, they neither attempt to account for the risk nor are they applied to very large areas. These gaps hamper a more focused and comprehensive identification of possible target areas for risk mitigation.

Here we demonstrate a novel model framework for the regional-scale analysis of high-mountain hazard and risk indicators. In contrast to a hazard and risk analysis, the results of this hazard and risk indicator analysis help to gain an idea about possible hazards and risks, but represent no direct information on the hazards and risks themselves as event frequencies, vulnerabilities and exposures are not considered in a strictly quantitative way.

The analysis includes (i) rock slides, commonly converting into rock avalanches or, in glacierized areas, into rock-ice avalanches, (ii) ice-avalanches, (iii) periglacial debris flows and (iv) lake outburst floods, often evolving into flows of debris or mud. Examples of these results of processes, or of situations possibly leading to their occurrence, are illustrated in Fig. 1. Process chains including more than one of the above process types are also considered. The study area in the Pamir (Tajikistan, Central Asia) is introduced in Sect. 2. The data used for the study is presented in Sect. 3 and the model framework is explained in detail in Sect. 4. Section 5 gives an overview of the model results which are discussed in Sect. 6. Section 7 summarizes the essence of the study.

\section{Study area}

A $98300 \mathrm{~km}^{2}$ study area in Central Asia is considered, extending from $1670 \mathrm{~m}$ a.s.l. near Kalai-Khumb to $7495 \mathrm{~m}$ a.s.l. at the top of Ismoili Somoni Peak and largely corresponding to the headwaters of the Amu Darya River (Fig. 2). The northern and southern boundaries of the area are formed by the Alai and Hindukush ranges in Kyrgyzstan and Afghanistan. In between, the Pamir in the GornoBadakhshan Autonomous Oblast of Tajikistan represents the largest share of the study area.

The western Pamir is characterized by glacierized mountain ranges exceeding $6000 \mathrm{~m}$ a.s.l. and deeply incised valleys. The eastern Pamir represents an arid highland above $3500 \mathrm{~m}$ a.s.l. with glaciers covering only the highest peaks. The more humid northern and central parts of the Pamir includes the Academy of Sciences and Trans-Alai ranges' peaks above $7000 \mathrm{~m}$ a.s.l. and is extensively glacierized. The Fedchenko Glacier extends over a length of $>75 \mathrm{~km}$ and covers a surface area $>700 \mathrm{~km}^{2}$.

Intense tectonic uplift, in combination with glacial and fluvial erosion (Mahmood et al., 2008), has resulted in a particularly pronounced relief. Consequently the geomorphic activity is high, including a large variety of mass wasting processes. These are commonly triggered by earthquakes as the seismic activity and, therefore, the seismic hazards are significant (Giardini et al., 1999). Few large historic events such as the 1911 Sarez rock slide (Schuster and Alford, 2004; Risley et al., 2006; see Fig. 1a) or the 1949 Khait rock avalanche (Evans et al., 2009b) are well documented. The deposit of the $2 \mathrm{~km}^{2}$ Sarez rock slide forms the $600 \mathrm{~m}$ high Usoi Dam, the highest dam worldwide. It retains the $60 \mathrm{~km}$-long Lake Sarez, the safety of which is still disputed (e.g. Risley et al., 2006).

The climate in the study area is temperate semi-arid to arid and continental with hot summers and cold winters. Most meteorological stations in the study area have recorded a positive trend of the mean annual air temperature 


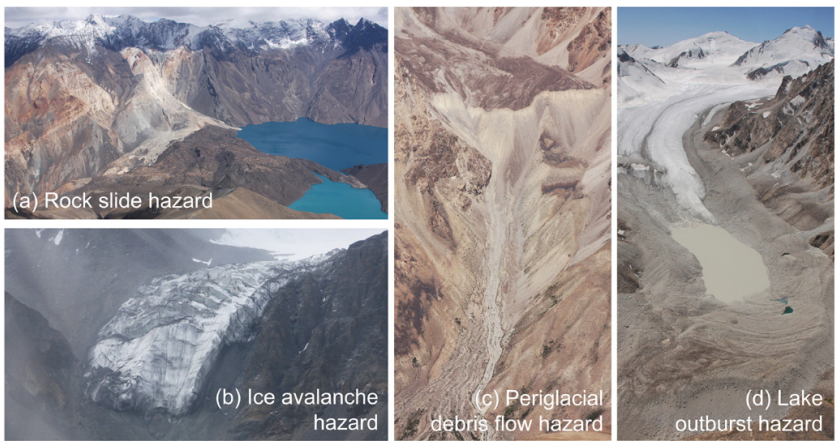

Fig. 1. Processes covered by the high-mountain multi-hazard and -risk indicator model. (a) The $2 \mathrm{~km}^{2}$ rock slide deposit impounding Lake Sarez, triggered by an earthquake in 1911, (b) hanging glacier in the Sauksay Valley prone to produce ice avalanches, (c) periglacial debris flow starting from a rock glacier terminus in the upper Gunt Valley, (d) Lake Varshedz in a southern tributary of the Gunt Valley, one of many glacial lakes possibly susceptible to sudden drainage. All photos taken by M. Mergili.

(MAAT) in the period 1940-2000 (Makhmadaliev et al., 2008). The state of information suffers from a lack of up-to-date high-altitude meteorological data. According to the 4th IPCC report (IPCC, 2007), the median of the projected increase of the MAAT from 1980-1999 to 2080-2099 for Tajikistan is $3.7^{\circ} \mathrm{C}$.

A number of studies document the retreat of many glaciers in the study area (e.g. Khromova et al., 2006; Haritashya et al., 2009; Mergili et al., 2012a), favouring the development of lakes in the glacier forefields or in subsiding areas on the glaciers. Mergili et al. (2013b) detected a total number of 652 glacial lakes in the study area. A GLOF in 2002 caused dozens of fatalities, several more lakes are susceptible to sudden drainage (Mergili and Schneider, 2011; see Fig. 1d). Furthermore, the retreat of glaciers over steep rock cliffs (see Fig. 1b) may lead to the increased occurrence of ice avalanches. The shift of the permafrost boundary to higher areas results in the possible destabilization of rock and debris. Periglacial debris flows observed in the study area are most commonly associated with the termini of rock glaciers (see Fig. 1c).

The valleys in the study area are fairly densely populated, with Khorog as the only urban centre (see Fig. 1). The local communities strongly depend on the natural resources and are therefore affected by the consequences of the changing temperature regime in both positive and negative ways (Kassam, 2009).

\section{Data}

The data the high-mountain multi-hazard and -risk indicator analysis builds on are summarized in Table 1. The ASTER GDEM V2, a product of METI and NASA, is used as input

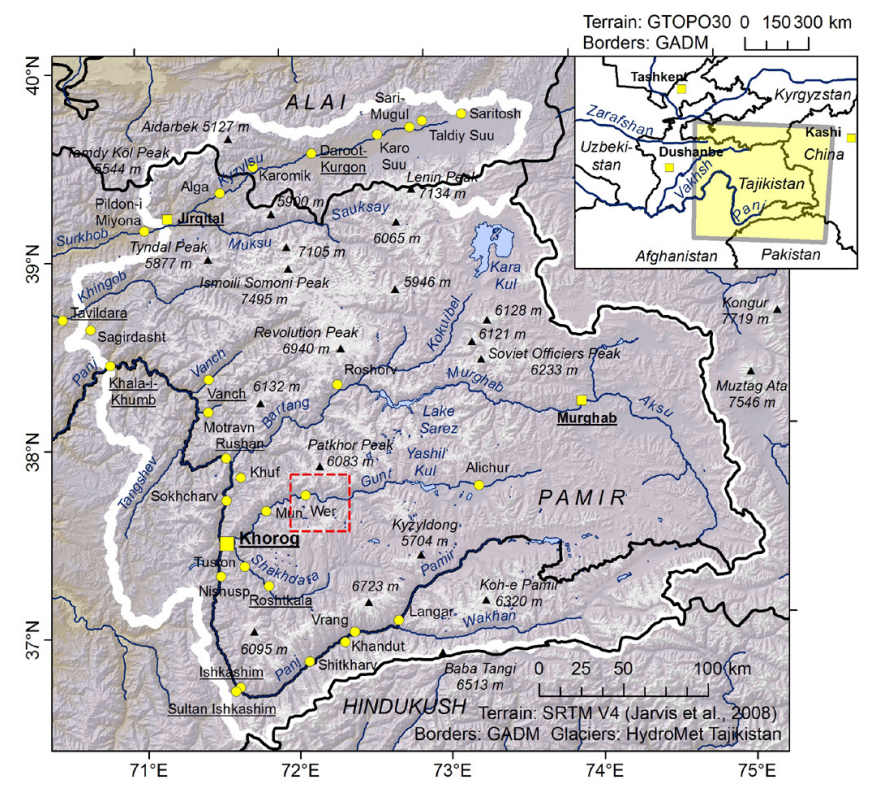

Fig. 2. Study area. The dashed red rectangle delimits the area shown in Fig. 11, the yellow polygon in the upper right inset indicates the extent of the main map.

digital elevation model (DEM). It is provided at a cell size of approximately $30 \mathrm{~m} \times 30 \mathrm{~m}$. Here a version resampled to $60 \mathrm{~m} \times 60 \mathrm{~m}$ (the cell size applied for modelling, see Sect. 4.1) is applied. Secondary data sets such as elevation with filled depressions, slope and flow direction are generated from the DEM which is further used to generate a gridded data set of the MAAT, making use of temperature data recorded at the stations of the Tajik HydroMet Agency and a vertical temperature gradient of $0.0062^{\circ} \mathrm{Cm}^{-1}$ (Müllebner, 2010; Fig. 3a).

The identification of areas with melting permafrost builds on the permafrost indication map for Tajikistan presented by Mergili et al. (2012a): a set of rules-of-thumb for the lower boundaries of areas with a potential for sporadic and discontinuous permafrost in Switzerland (Haeberli, 1975) is adapted to the conditions in Tajikistan, based on the difference in the $0^{\circ} \mathrm{C}$ isotherm of the MAAT. This set of rules is then combined with the DEM in order to produce a gridded data set indicating the possibility of permafrost occurrence for each raster cell. Applying the temperature gradient of Müllebner (2010), the effects of atmospheric temperature increase on permafrost distribution are explored. Areas where the model predicts either sporadic or discontinuous permafrost for the current state, but no permafrost of either of the two types for a temperature increase of +2 or $+4{ }^{\circ} \mathrm{C}$, represent separate classes. Such areas are of particular interest for the permafrost susceptibility score $S_{\mathrm{p}}$ (Fig. 3b; see Sect. 4).

The seismic susceptibility of the area $S_{\mathrm{s}}$ is defined according to the peak ground acceleration with $10 \%$ chance of exceedance in $50 \mathrm{yr}$ (PGA), expressed in relation to gravity $g$. 
Table 1. Input data, rm - raster map, tc - table column.

\begin{tabular}{|c|c|c|}
\hline Parameter & Data type & Source \\
\hline Elevation & rm, ma.s.l. & ASTER GDEM V2, a product of METI and NASA \\
\hline Glaciers & $\mathrm{rm}$, boolean & Semi-automated classification of Landsat 7 imagery \\
\hline Lake ID & rm, nominal & Manual mapping from ASTER and Landsat imagery (Mergili et al., 2013b) \\
\hline \multicolumn{3}{|l|}{ For each lake: } \\
\hline $\begin{array}{l}\text { Lake type } \\
\text { Lake drainage }\end{array}$ & $\begin{array}{l}\text { tc, nominal } \\
\text { tc, boolean }\end{array}$ & $\begin{array}{l}\text { Qualitative interpretation of ASTER, Landsat } \\
\text { and Google Earth }{ }^{\circledR} \text { imagery (Mergili et al., 2013b) }\end{array}$ \\
\hline Calving of ice & tc, boolean & \\
\hline Lake area $A_{1}$ & $\mathrm{tc}, \mathrm{m}^{2}$ & Derived from mapped lakes \\
\hline Lake evolution & tc, boolean & $\begin{array}{l}\text { Mapped, } 75 \% \text { confidence of growing trend in at least one of } \\
\text { the periods 1968-2002 and 2002-2009 (Mergili et al., 2013b) }\end{array}$ \\
\hline Mean annual air temperature (MAAT) & $\mathrm{rm},{ }^{\circ} \mathrm{C}$ & $\begin{array}{l}\text { Temperature map of Müllebner (2010) based on regression of data } \\
\text { recorded by the Tajik HydroMet Agency with elevation }\end{array}$ \\
\hline Permafrost susceptibility $S_{\mathrm{p}}$ & rm, nominal & $\begin{array}{l}\text { Permafrost indication map of Mergili et al. (2012a) for Tajikistan, } \\
\text { based on the adaptation of the rules-of-thumb of Haeberli (1975) }\end{array}$ \\
\hline Seismic susceptibility $S_{\mathrm{S}}$ & $\mathrm{rm}, g$ & $\begin{array}{l}\text { GSHAP Global Seismic Hazard Map (Giardini et al., 1999): } \\
\text { peak ground acceleration (PGA) with } 10 \% \text { chance of exceedance in } 50 \mathrm{yr}\end{array}$ \\
\hline $\begin{array}{l}\text { Exposure } E \\
\text { Community ID }\end{array}$ & $\begin{array}{l}\mathrm{rm}, \text { nominal } \\
\mathrm{rm} \text {, nominal }\end{array}$ & $\begin{array}{l}\text { Manual mapping of land use from ASTER, Landsat } \\
\text { and Google Earth }{ }^{\circledR} \text { imagery }\end{array}$ \\
\hline
\end{tabular}

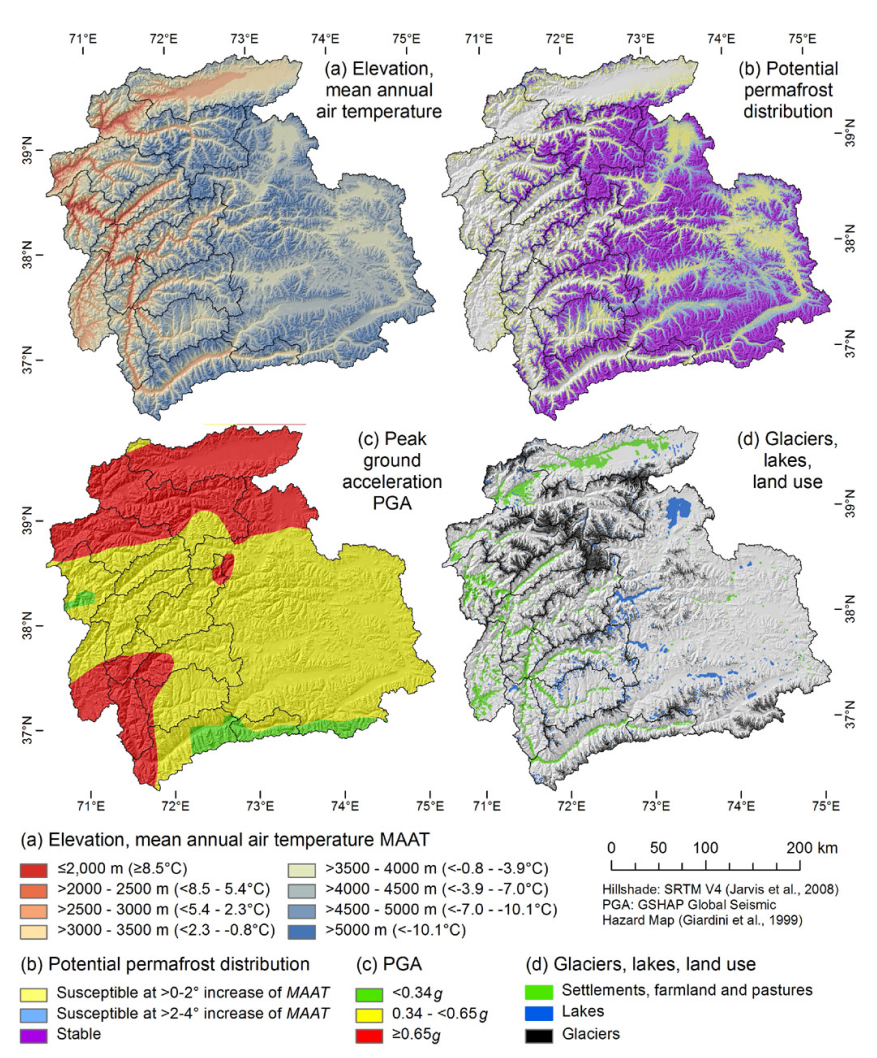

Fig. 3. Input data: (a) elevation and mean annual air temperature, (b) potential permafrost distribution, (c) peak ground acceleration, and (d) mapped glaciers, lakes and land use.
The Global Seismic Hazard Map (Giardini et al., 1999), an outcome of the Global Seismic Hazard Assessment Program (GSHAP), is employed (see Fig. 3c).

A raster map representing the glaciers in the study area is generated by a semi-automated classification of Landsat 7 satellite imagery of 2001. Three classes are distinguished: debris-covered glacier, glacier with exposed ice and no glacier (see Fig. 3d). The lakes in the study area are covered by the comprehensive lake inventory presented by Mergili et al. (2013b), providing detailed information on 1640 lakes (see Table 1; see Fig. 3d). Besides the tabular information, a raster map with the unique ID of each lake is used.

An indicator for the exposure of the communities in the study areas to high-mountain hazards is generated from a raster map depicting the land use associated with each cell (Fig. 3d illustrates the distribution of areas with significant land use) derived by the qualitative interpretation of ASTER, Landsat and Google Earth ${ }^{\circledR}$ imagery. Table 2 shows the key used for deriving the exposure indicator $E$ from the land use map, taking values in the range $0-4$. Linear structures such as roads or power lines are not considered. Each raster cell with $E>0$ is associated to one of the 628 communities identified in the study area. The communities largely correspond to the villages depicted in the Soviet Topographic Maps at scales of $1: 50000$ and $1: 100000$. However, two or more villages are grouped to one community in cases where cells with $E>0$ cannot clearly be assigned to one specific village. 


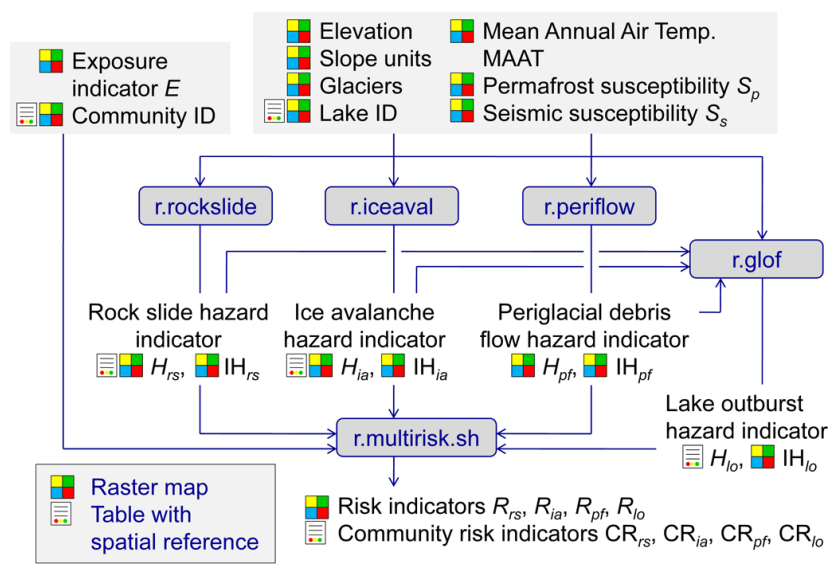

Fig. 4. Logical framework of the high-mountain multi-hazard and -risk indicator model.

\section{Model}

\subsection{Concept of the multi-hazard and -risk indicator analysis}

The high-mountain multi-hazard and -risk indicator computer model is implemented with the open-source software package GRASS GIS (Neteler and Mitasova, 2007; GRASS Development Team, 2013). This software builds on a flexible modular design. Simple bash scripting can be used to facilitate work flows by combining existing modules. Furthermore, new modules can be added by individual developers, so that the standard GIS functions are complemented by a large array of more specialized applications. Such applications can be used individually or made publicly available. Examples of mountain hazard models implemented with GRASS GIS include r.debrisflow (Mergili et al., 2012b), r.avalanche (Mergili et al., 2012c) and r.rotstab (Mergili et al., 2013a). The model presented here builds on a combination of newly developed or upgraded modules and bash scripts. The logical framework of the model is illustrated in Fig. 4, the modules dealing with the specific process types are detailed in Sects. 4.2-4.5. The model is executed at a raster cell size of $60 \mathrm{~m} \times 60 \mathrm{~m}$.

The high-mountain hazard indicator analysis procedure applied at the regional scale aims at the identification of possible (i) source areas and (ii) impact areas of hazardous processes. The risk indicator analysis combines the indicator for hazard in the impact areas; that is, the impact hazard indicator IH with the exposure indicator $E$ there in order to derive a risk indicator $R$ in the range $0-6$. Table 2 shows the matrix employed for the combination of IH and $E$.

The following types of processes are considered: (i) rock slides, (ii) ice avalanches, (iii) periglacial debris flows and (iv) lake outburst floods. All of them show a potential for long travel distances and therefore represent a significant threat for the populated areas in the valleys. Even though each process type is considered separately, interactions are

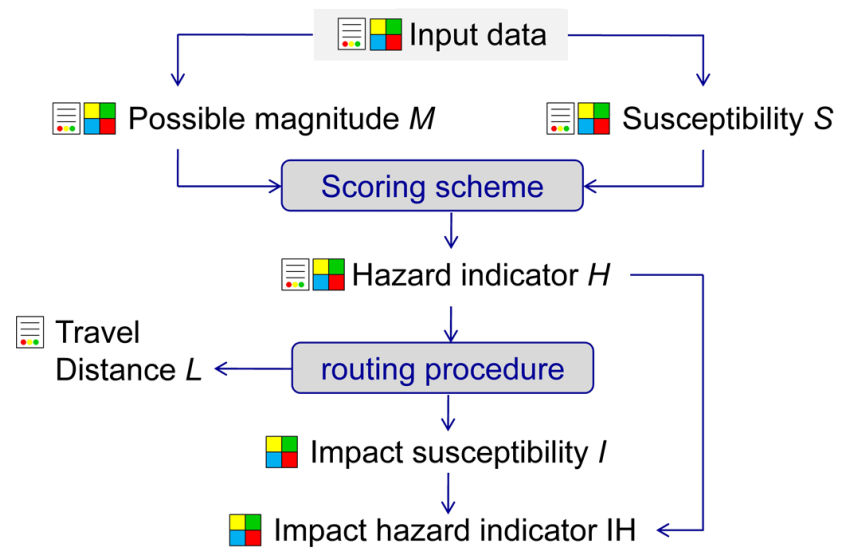

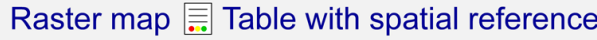

Fig. 5. Simplified logical framework valid for each of the four modules r.rockslide, r.iceaval, r.periflow and r.glof. The specific characteristics of each module are outlined in Sects. 4.2-4.5.

included in the model, such as triggering of a lake outburst flood by the impact of an upslope mass movement (see Fig. 4).

The scoring scheme employed for the hazard indicator analysis follows the same basic principle for all types of processes (Fig. 5). It builds on susceptibility, hazard and risk indicators to be understood as ordinal numbers, not allowing for the use of arithmetic operations. Two-dimensional matrices are therefore used, all indicators can take values in the range of 0-6 (Tables 3 and 4).

The hazard indicator $H$ for the onset of a process is computed by combining a score for the susceptibility $S$ with a score for the possible process magnitude $M$ (see Fig. 5). The susceptibility is understood as the tendency of a lake, part of a glacier or slope to produce an event and acts as a surrogate for the frequency. The possible process magnitude is based on the possible onset volume (rock slides) or on the possible onset area (ice avalanches, lake outburst floods; see Table 3).

The impact susceptibility represents the tendency of a GIS raster cell to be affected by one of the considered processes. It is derived by routing the mass movement from the onset area down through the DEM. At the regional scale, empirical relationships are suitable for relating the travel distance $L$ or the angle of reach $\omega_{\mathrm{r}}$ of a flow to the involved volume $V$ or the peak discharge $Q_{\mathrm{p}}$, or for defining a global value of $\omega_{\mathrm{r}}$. The appropriate values or relationships are employed for each process type, applying the lower envelope $\left(\omega_{\mathrm{r}, \mathrm{E}}\right.$, maximum travel distance) and the average $\omega_{\mathrm{r}, \mathrm{A}}$ usually observed for the considered process (see Sects. 4.2-4.5). A random walk procedure weighted for local slope and maintenance of flow direction is applied for routing. This, by applying a sufficiently large number of random walks, ensures a certain degree of lateral spreading. Furthermore, the linear distance from the starting point has to increase with each step of the 
Table 2. Risk indicator $R$ : combination of the impact hazard indicator IH (see Sect. 4.1) and the exposure indicator $E$ with scoring scheme for $E$ as a function of land use.

\begin{tabular}{lllllllll}
\hline$E \downarrow \mathrm{IH} \rightarrow$ & Land use & 6 & 5 & 4 & 3 & 2 & 1 & 0 \\
\hline 4 (Higher) & Built-up areas, often mixed with farmland or pastures & 6 & 5 & 4 & 3 & 2 & 1 & 0 \\
3 & Farmland or pastures with some buildings & 5 & 4 & 3 & 2 & 1 & 1 & 0 \\
2 & Farmland, pastures or forest with no or few buildings & 4 & 3 & 2 & 1 & 1 & 1 & 0 \\
1 & Extensively used or temporarily unused land & 3 & 2 & 1 & 1 & 1 & 1 & 0 \\
0 (Lower) & No identifiable land use & 0 & 0 & 0 & 0 & 0 & 0 & 0 \\
\hline
\end{tabular}

Table 3. Hazard indicator $H$ : combination of $S$ and $M$, with thresholds of (a) rock slide volume $V_{\mathrm{rs}}\left(10^{6} \mathrm{~m}^{3}\right)$, (b) area of hanging glacier $A_{\mathrm{a}}$ $\left(10^{3} \mathrm{~m}^{2}\right)$ and (c) lake area $A_{1}\left(10^{3} \mathrm{~m}^{2}\right)$.

\begin{tabular}{lrrrrrrrrrr}
\hline$M \downarrow S \rightarrow$ & $(\mathrm{a})$ & $(\mathrm{b})$ & $(\mathrm{c})$ & 6 & 5 & 4 & 3 & 2 & 1 & 0 \\
\hline 6 (Higher) & $\geq 24.3$ & $\geq 200.0$ & $\geq 200.0$ & 6 & 6 & 5 & 5 & 4 & 3 & 0 \\
5 & $8.1-<24.3$ & $100.0-<200.0$ & $100.0-<200.0$ & 6 & 5 & 5 & 4 & 3 & 2 & 0 \\
4 & $2.7-<8.1$ & $50.0-<100.0$ & $50.0-<100.0$ & 5 & 5 & 4 & 4 & 3 & 2 & 0 \\
3 & $0.9-<2.7$ & $25.0-<50.0$ & $25.0-<50.0$ & 5 & 4 & 4 & 3 & 3 & 2 & 0 \\
2 & $0.3-<0.9$ & $12.5-<25.0$ & $12.5-<25.0$ & 4 & 3 & 3 & 3 & 2 & 2 & 0 \\
1 & $0.1-<0.3$ & $5.0-<12.5$ & $5.0-<12.5$ & 3 & 2 & 2 & 2 & 2 & 1 & 0 \\
0 (Lower) & $<0.1$ & $<5.0$ & $<5.0$ & 0 & 0 & 0 & 0 & 0 & 0 & 0 \\
\hline
\end{tabular}

routing procedure. For each passed cell, the average slope angle from the starting point, $\omega$, is updated. Each random walk terminates as soon as $\omega \leq \omega_{\mathrm{r}, \mathrm{E}}$. The impact susceptibility score $I$ of each cell builds on the maximum of the ratio

$r_{\omega}=1-\frac{\tan \omega_{\mathrm{r}, \mathrm{A}}-\tan \omega}{\tan \omega_{\mathrm{r}, \mathrm{A}}-\tan \omega_{\mathrm{r}, \mathrm{E}}}$

over all random walks. $r_{\omega}=1$ at the average angle of reach and $r_{\omega}=0$ at the lower envelope (see Table 4). $I$ is determined separately for each hypothetic event. The impact hazard indicator IH map, discretized on the basis of GIS raster cells, is derived by combining $H$ and $I$ (see Fig. 5).

As the final step of the hazard indicator analysis, the impact hazard indicators for all hypothetic events are combined in order to derive a raster map of the global impact hazard indicator $\mathrm{IH}$ :

$\mathrm{IH}=\max \left(\mathrm{IH}_{1}, \mathrm{IH}_{2}, \ldots, \mathrm{IH}_{n}\right)$,

where the subscripts $i=1,2, \ldots, n$ represent the hypothetic event $\mathrm{IH}_{i}$ is associated with, and $n$ is the total number of possible onset areas for the considered process type.

Whilst the general concept outlined is applied to all types of hazards, the specific procedures for each process type are detailed in Sects. 4.2-4.5. Below, the subscript rs stands for rock slides, ia for ice avalanches, pf for periglacial debris flows and lo for lake outburst floods. Maps of IH and $R$ are determined separately for each process.

Given the uncertainties inherent to the regional-scale hazard and risk indicator analysis, the discretization of the results at a raster cell size of $60 \mathrm{~m} \times 60 \mathrm{~m}$ may pretend a level
Table 4. Impact hazard indicator IH: combination of $H$ and $I, r_{\omega}$ is computed according to Eq. (1).

\begin{tabular}{lllllllll}
\hline$I \downarrow H \rightarrow$ & $r_{\omega}$ & 6 & 5 & 4 & 3 & 2 & 1 & 0 \\
\hline 6 (Higher) & $\geq 2.000$ & 6 & 6 & 5 & 5 & 4 & 3 & 0 \\
5 & $1.500-<2.000$ & 6 & 5 & 5 & 4 & 3 & 2 & 0 \\
4 & $1.000-<1.500$ & 5 & 5 & 4 & 4 & 3 & 2 & 0 \\
3 & $0.667-<1.000$ & 5 & 4 & 4 & 3 & 3 & 2 & 0 \\
2 & $0.333-<0.667$ & 4 & 3 & 3 & 3 & 2 & 2 & 0 \\
1 & $0.000-<0.333$ & 3 & 2 & 2 & 2 & 2 & 1 & 0 \\
0 (Lower) & $<0.000$ & 0 & 0 & 0 & 0 & 0 & 0 & 0 \\
\hline
\end{tabular}

of detail not supported by the methodology used. According to the purpose of the study, the prioritization of target communities for risk mitigation measure, community-based risk indicators for each process type $\left(\mathrm{CR}_{\mathrm{rs}}, \mathrm{CR}_{\mathrm{ia}}, \mathrm{CR}_{\mathrm{pf}}, \mathrm{CR}_{\mathrm{lo}}\right)$ are derived. The maxima of the raster cell-based risk indicators over all cells representing the considered village are applied. However, if the highest risk indicator $R$ assigned to a community applies to an area $<10000 \mathrm{~m}^{2}$, CR is reduced by 1 . In such cases a lower indicator class of $R$, if it applies to a larger area, may determine the CR class for the community.

\subsection{Rock slide hazard indicator}

The GRASS raster module employed for the rock slide hazard indicator analysis is named r.rockslide and, to some extent, builds on the approach of Hergarten (2012).

Loops over all raster cells within the study area are performed separately for four assumptions of sliding plane inclination $\beta_{\mathrm{s}, \mathrm{i}}$ (Table 5). If the local slope $\beta>\beta_{\mathrm{s}, \mathrm{i}}$ for a tested 
Table 5. Rock slide susceptibility score $S_{\text {rs }}$. The initial values of $S_{\text {rs }}$ are determined from the sliding plane inclination $\beta_{\mathrm{s}, \mathrm{i}}$, these values are then increased according to permafrost susceptibility and seismic susceptibility, $g$ is gravity $\left(\mathrm{m} \mathrm{s}^{-2}\right)$.

\begin{tabular}{llr}
\hline Criterion & Remarks & $S_{\mathrm{rs}}$ \\
\hline Sliding plane & $\tan \left(\beta_{\mathrm{s}, \mathrm{i}}\right) \geq 1.000-<1.333$ & 1 \\
inclination $\beta_{\mathrm{s}, \mathrm{i}}$ & $\tan \left(\beta_{\mathrm{s}, \mathrm{i}}\right) \geq 1.333-<1.667$ & 2 \\
& $\tan \left(\beta_{\mathrm{s}, \mathrm{i}}\right) \geq 1.667-<2.000$ & 3 \\
& $\tan \left(\beta_{\mathrm{s}, \mathrm{i}}\right) \geq 2.000$ & 4 \\
\hline Permafrost & No permafrost or stable permafrost & \pm 0 \\
susceptibility & Susceptible to melting & +1 \\
& at $\Delta \mathrm{MAAT}>0-4^{\circ}$ & \\
\hline Seismic & PGA $<0.34 g$ & \pm 0 \\
susceptibility & $\mathrm{PGA} \geq 0.34-<0.65 g$ & +1 \\
& $\mathrm{PGA} \geq 0.65 g$ & +2 \\
\hline
\end{tabular}

cell, the cell is considered as a seed cell for a possible rock slide. In order to simulate a progressive failure, an inverse cone with a vertical axis and an inclination of $\beta_{\mathrm{s}, \mathrm{i}}$ is introduced. The apex of this cone coincides with the seed cell. All material above the cone surface (terrain elevation $>$ cone elevation) is considered as potential rock slide material, imitating a rock slide involving all over-steepened terrain with respect to the base cell. For each seed cell, the volume $V_{\mathrm{rs}}$ removed by the associated rock slide is recorded.

The susceptibility score $S_{\text {rs }}$ for each cell with terrain elevation $>$ cone elevation is determined according to Table 5 , including the sliding plane inclination $\beta_{\mathrm{s}, \mathrm{i}}$ and the permafrost susceptibility $S_{\mathrm{p}}$ as conditioning factors, and the seismic susceptibility $S_{\mathrm{s}}$ as possible triggering factor. $S_{\mathrm{rs}}$ can take values in the range of 0-6. The rock slide hazard indicator $H_{\mathrm{rs}}$ is computed according to Table 3, with the possible event magnitude represented by the rock slide volume $V_{\mathrm{rs}}$. Each cell may possibly be affected by rock slides from more than one seed cell. The final hazard indicator for each raster cell is defined as the maximum of $H_{\mathrm{rs}, i}$ out of all relevant possible rock slides $i$ :

$H_{\mathrm{rs}}=\max \left(H_{\mathrm{rs}, 1}, H_{\mathrm{rs}, 2}, \ldots, H_{\mathrm{rs}, n}\right)$,

where the indices $1,2, \ldots n$ identify the considered possible rock slide, and $n$ is the number of possible rock slides.

The expected travel distance is estimated separately for each single possible slide, using a relationship of the type

$\log _{10} \tan \omega_{\mathrm{r}}=a \log _{10} V_{\mathrm{r}}+b$,

where $\omega_{\mathrm{r}}$ is the angle of reach and $V_{\mathrm{rs}}$ is the rock slide volume. The curve has to be cut off at $\tan \omega=\tan \varphi$, where $\varphi$ is the angle of repose. Equation (4) is only valid as long as the slide starts from rest. $a$ and $b$ depend on the process type, $b$ can also be varied in order to account for uncertainties of the relationship used. The following two relationships are applied.

1. For rock slides in non-glacierized areas, the prediction curve suggested by Scheidegger (1973) is used. It was derived from a set of 33 historic and prehistoric events. The correlation coefficient is 0.82 , the standard deviation is 0.14298. $a=-0.15666, b=0.62419$ for the average and 0.36418 for the envelope.

2. It is well established that rock slides in glacierized areas often convert into rock-ice avalanches with longer travel distances (Evans and Clague, 1988; Bottino et al., 2002). If the rock slide starts in a glacierized area, or as soon as it moves over a glacier, the relationship suggested by Noetzli et al. (2006) is applied: $a=-0.103, b=0.165$ for the average and -0.040 for the envelope.

The steeper regression line for non-glacierized areas results in the prediction of longer travel distances by the Scheidegger (1973) model for very large volumes $\left(V_{\mathrm{r}}>361 \times\right.$ $10^{3} \mathrm{~m}^{3}$ for the regression, $V_{\mathrm{r}}>34 \times 10^{63}$ for the envelope). This phenomenon has no physical basis but can most likely be attributed to a lack of very large events in the data set used by Noetzli et al. (2006). In the r.rockslide model, the relationship yielding the longer travel distance is used for rock slides in glacierized areas. Further, the run-up height RH at the opposite slope is limited by the envelope of the regression derived from the data set presented by Hewitt et al. (2008):

$\log _{10} \mathrm{RH} \leq 0.375 \log _{10} V_{\mathrm{r}}-0.62077$.

100 random walks are performed for each rock slide or rock-ice avalanche, each of them starting at the highest raster cell of the hypothetic failure plane. The impact susceptibility score $I_{\mathrm{rs}}$ and the impact hazard indicator $\mathrm{IH}_{\mathrm{rs}}$ are finally derived according to Eqs. (1) and (2) and Table 4. Equation (1) is here applied with the logarithms of $\tan \omega, \tan \omega_{\mathrm{r}, \mathrm{E}}$ and $\tan \omega_{\mathrm{r}, \mathrm{A}}$.

\subsection{Ice avalanche hazard indicator}

The slope beyond which glaciers or portions of glaciers are susceptible to produce ice avalanches depends on the properties of the ice, which are strongly determined by the ice temperature. As data on ice temperature is not commonly available, mean annual air temperature is often used as a surrogate. Huggel et al. (2004a) state that temperate glaciers produce ice avalanches at slopes above $25^{\circ}$, and cold glaciers at slopes above $45^{\circ}$. Here, a set of 11 cases (Alean, 1985; Huggel et al., 2004a) is taken as the basis for devising a scheme for ice avalanche susceptibility $S_{\text {ia }}$ (Fig. 6). The module r.iceaval builds on a quadratic regression fitted for this purpose, with

$\tan \beta=3.2 \times 10^{-3} \mathrm{MAAT}^{2}-2.03 \times 10^{-2} \mathrm{MAAT}+\eta$, 


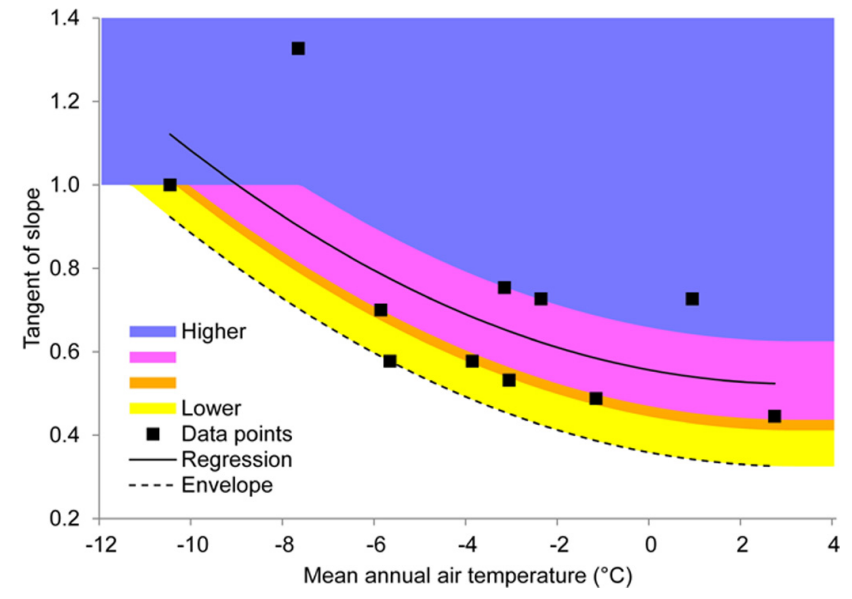

Fig. 6. Scoring scheme applied for ice avalanche susceptibility according to data presented by Alean (1985) and Huggel et al. (2004a).

where $\beta$ is the slope and MAAT is the mean annual air temperature $\left({ }^{\circ} \mathrm{C}\right)$. The intercept $\eta=0.5555$ for the regression and 0.357672 for the envelope. The thresholds applied to the ice avalanche susceptibility classes $S_{\mathrm{ia}}=0-4$ are determined from Eq. (1) with $\eta$ set in the way to split the data set into quartiles (see Fig. 6). $S_{\text {ia }}$ is increased according to the seismic susceptibility (see Table 1 ) so that the possible score values cover a range of $0-6$.

Next, clusters of cells with $S_{\mathrm{ia}}>0$ are identified. $S_{\mathrm{ia}}$ is increased by 1 for all clusters at glacier termini (no abutment). The ice avalanche hazard indicator $H_{\mathrm{ia}}$ is derived according to Table 3, combining $S_{\mathrm{ia}}$ and the area of each cluster.

For each cluster, 100 random walks are applied for routing the possible ice avalanche down, starting at the highest point of the cluster. According to Huggel et al. (2004a), the travel path of ice avalanches is constrained by an average slope of $17^{\circ}$, except for very large events $\left(>5 \times 10^{6} \mathrm{~m}^{3}\right)$. However, such events are most commonly rock-ice avalanches or complex process chains (e.g. 1962 and 1970 Huascarán events, 2002 Kolka-Karmadon event), which are covered separately here, or related to volcanic processes (1980 Iliamna event, Alaska). Therefore, and since the ice avalanche volume cannot be derived with the method applied, we constrain the impact area with an average slope of $17^{\circ}\left(\tan \omega_{\mathrm{r}, \mathrm{E}}=0.31\right)$. In the data set used by Huggel et al. (2004a), the minimum value of the average slope is $\tan \omega=0.44, \tan \omega_{\mathrm{r}, \mathrm{E}}$ is set to the average 0.375 and $I_{\mathrm{ia}}$ is computed according to Eq. (1). Equation (2) and Table 4 are applied in order to derive the ice avalanche impact hazard indicator $\mathrm{IH}_{\text {ia }}$.

\subsection{Periglacial debris flow hazard indicator}

Melting permafrost on steep slopes leaves behind a certain amount of loose debris susceptible to mobilization as debris flows. Such processes may occur in the active layer, but even
Table 6. Scoring scheme for periglacial debris flow susceptibility $S_{\mathrm{pf}}$.

\begin{tabular}{llr}
\hline Criterion & Remarks & $S_{\mathrm{lo}, \mathrm{i}}$ \\
\hline & $\tan \beta<0.5$ & 0 \\
& $\tan \beta \geq 0.5-<0.6$ & 1 \\
Slope $\beta$ & $\tan \beta \geq 0.6-<0.7$ & 2 \\
& $\tan \beta \geq 0.7-0.8$ & 3 \\
& $\tan \beta>0.8$ & 0 \\
\hline Permafrost & No permafrost or stable permafrost & 0 \\
susceptibility & Susceptible to melting at & \pm 0 \\
& $\Delta$ MAAT $>0-2^{\circ}$ & +2 \\
\hline Seismic & PGA $<0.65 g$ & \pm 0 \\
susceptibility & PGA $\geq 0.65 g$ & +1 \\
\hline
\end{tabular}

more where permafrost is retreating. Here, we only consider areas where retreating permafrost is assumed (see Table 1; Mergili et al., 2012a). Huggel et al. (2004b) noted that, in contrast to ordinary debris flows, parameters such as slope curvature or the proximity to the stream network are hardly significant for the onset of such processes. Further, they commonly occur at slope angles of $27-38^{\circ}$. Table 6 shows the scheme applied here, in the module r.periflow, for deriving the susceptibility of each raster cell to periglacial debris flows $S_{\mathrm{pf}}$ in the range of 0-6. We follow the findings of Huggel et al. (2004b) with regard to slope. Unfortunately, no means for the reliable distinction of bedrock and debris at the relevant scale are known to the authors. Besides slope and the state of the permafrost, the seismic susceptibility is considered for deriving $S_{\mathrm{pf}}$ (see Tables 1 and 6).

In contrast to the other processes considered in the present study, there are no means to approximate the onset volume and therefore the process magnitude. Clusters of susceptible cells are often large whilst the onset of debris flow processes is most commonly a rather localized process. We therefore use the approximation $H_{\mathrm{pf}}=S_{\mathrm{pf}}$.

Consequently, the routing procedure (i) has to be started separately from each raster cell with $S_{\mathrm{pf}}>0$, and (ii) the average slope determining the impact area has to be independent from volume. Due to the commonly large clusters of starting cells, only 10 random walks are started from each cell. Huggel et al. (2004b) give an envelope average slope of the travel path of $11^{\circ}\left(\tan \omega_{\mathrm{r}, \mathrm{E}}=0.194\right)$ which is also applied here. The maximum average slope is taken from Corominas et al. (2003), who provide a value of $26^{\circ}(\tan \omega=0.488)$ for debris flows $<800 \mathrm{~m}^{3}$ propagating on undisturbed flow paths assumed for the study area. The average of the two values, 0.341 , is taken as $\tan \omega_{\mathrm{r}, \mathrm{A}} . I_{\mathrm{pf}}$ is computed according to Eq. (1). For $I_{\mathrm{pf}}<4$, the run-up on the opposite slope is restricted. Equation (2) and Table 4 are applied to derive the periglacial debris flow impact hazard indicator $\mathrm{IH}_{\mathrm{pf}}$. 


\subsection{Lake outburst hazard indicator}

An improved version of the GRASS GIS raster module r.glof (Mergili and Schneider, 2011) is used for the lake outburst hazard indicator analysis.

First, the susceptibility scores for (i) lake outburst caused by internal factors (dam failure) $S_{\mathrm{lo}, \mathrm{i}}$ and (ii) lake outburst triggered by external factors (impact of mass movements) $S_{\mathrm{lo}, \mathrm{e}}$ are considered separately. $S_{\mathrm{lo}, \mathrm{i}}$ and $S_{\mathrm{lo}, \mathrm{e}}$ can take values in the range of $0-6$, negative values are set to 0 .

The derivation of $S_{\mathrm{lo}, \mathrm{i}}$ builds on the following key parameters: (i) lake type, indicating the dam material; (ii) mode of lake drainage; (iii) lake evolution (development of the lake area since 1968; Mergili et al., 2013b); (iv) dam geometry; (v) permafrost susceptibility; and (vi) seismic susceptibility (see Table 1). Table 7 shows the scoring scheme applied. The lake type (Mergili et al., 2013b) is taken as basis, with glacial lakes receiving the highest score. Dams with seepage are considered more susceptible to failure than dams with surface runoff, and growing lakes are considered more susceptible than stable or shrinking ones. The dam geometry is expressed as an idealized average downstream slope of the dam: the dam width $W$ is defined as the Euclidean distance between the lake outlet and the closest raster cell along the downstream flow path with a lower elevation than the average lake bottom, using the average lake depth $D_{1}$ according to Huggel et al. (2002):

$D_{1}=1.04 \times 10^{-1} A_{1}^{0.42}$,

where $A_{1}$ is the lake area $\left(\mathrm{m}^{2}\right), D_{1}$ is given in $\mathrm{m}$. The tangent of the average slope of the dam in outflow direction, $\tan \beta_{\mathrm{d}}$, is derived as $D_{1} / W$. For very gentle downstream average slopes $\tan \beta_{\mathrm{d}}<0.02, S_{\mathrm{lo}, \mathrm{i}}$ is decreased by 1 (see Table 7).

The event at Laguna 513 in the Cordillera Blanca (Haeberli et al., 2010b) has shown the need to include the entire catchment when analysing lake outburst susceptibility. The topographic susceptibility TS is introduced in order to account for this need, employing the impact hazard indicators for rock slides $\mathrm{IH}_{\mathrm{rs}}$, for ice avalanches $\mathrm{IH}_{\mathrm{ia}}$, for periglacial debris flows $\mathrm{IH}_{\mathrm{pf}}$, and for outburst floods of lakes in the upper catchment $\mathrm{IH}_{1 \mathrm{o}}$. The overall maximum indicator over the raster cells representing the considered lake $\left(\mathrm{IH}_{\mathrm{ia}, \max }\right.$, $\mathrm{IH}_{\mathrm{rs} \text {,max }}, \mathrm{IH}_{\mathrm{pf} \text {,max }}$ and $\left.\mathrm{IH}_{\mathrm{lo,max}}\right)$ applies, but the impact of periglacial debris flows and upstream lake outburst floods is down-weighted:

$\mathrm{TS}=\max \left(\mathrm{IH}_{\mathrm{rs}, \max }, \mathrm{IH}_{\mathrm{ia}, \max }, \mathrm{IH}_{\mathrm{pf}, \max }-3, \mathrm{IH}_{\mathrm{lo}, \max }-3\right)$.

The topographic susceptibility is taken as the basis for the rating of the susceptibility to lake outburst triggered by external factors $S_{\mathrm{lo}, \mathrm{e}}$. If direct calving of ice into the lake is possible, the score for $S_{\mathrm{lo}, \mathrm{e}}$ is set to a minimum of 3 .

The maximum of $S_{\mathrm{lo}, \mathrm{i}}$ and $S_{\mathrm{lo}, \mathrm{e}}$ is used as lake outburst susceptibility $S_{\mathrm{lo}}$. $S_{\mathrm{lo}}$ is reduced for lakes with a high freeboard $F$ (defined as the difference between the DEM with filled sinks and the original DEM for the lake centre): for lakes with $F>50 \mathrm{~m}$ the score is decreased by 3 . For lakes with $F>25 \mathrm{~m}$ it is decreased by 2 , and for lakes with $F>$ $10 \mathrm{~m}$, the score is decreased by 1 in order to derive the final value of $S_{\mathrm{lo}}$.

The lake area is most likely the best surrogate for $M_{\mathrm{lo}}$ (the computed lake volume is directly proportional to the lake area, see Eq. 7). Table 7 shows the matrix for the lake outburst hazard indicator $H_{\mathrm{lo}}$ which is discretized on the basis of lakes.

Possible outburst floods are routed downwards through the DEM separately for each lake, the travel distance is determined according to the relationships listed in Table 8 . After the deposition of the debris or mud, or if not much sediment is entrained at all, the flood may propagate much farther: Haeberli (1983) suggests an average angle of reach of $2-3^{\circ}$, but also travel distances exceeding $200 \mathrm{~km}$ are reported (e.g. Hewitt, 1982).

In order to achieve a robust estimate of the travel distance, the impact area of possible lake outburst floods and, consequently, the impact susceptibility $I_{\mathrm{lo}}$, the approaches T1-T4 shown in Table 8 are combined (Eq. 1 is not applied for lake outburst floods). The lake outburst flood is routed down starting from the outlet of the considered lake. A total of 800 random walks are performed for each lake. A random walk is forced to terminate if it impacts a larger lake.

For T1, the debris flow volume $V_{\mathrm{d}}$ is set to five times the outburst volume (maximum sediment concentration in steep flow channels $\sim 80 \%$ according to Iverson, 1997) in order to account for sediment bulking. The outburst volume is set to the entire lake volume (lake area $A_{1}$ multiplied with lake depth $D_{1}$ ). For T2, we use an angle of reach $\omega_{\mathrm{r}}=8^{\circ}$ which is most likely more suitable for the study area (Mergili and Schneider, 2011) than $\omega_{\mathrm{r}}=11^{\circ}$ as suggested by Haeberli (1983). Several authors have introduced empirical relationships for relating the peak discharge $Q_{\mathrm{p}}\left(\mathrm{m}^{3} \mathrm{~s}^{-1}\right)$ - required as input for the relationship T3 in Table 8 - to the outburst volume and the dam height (Costa, 1985; Costa and Schuster, 1988; Walder and O'Connor, 1997; Table 9). $Q_{\mathrm{p}}$ is determined from the maximum of the results computed with the relationships Q1-Q6 shown in Table 9. T1 and T3 are only applied to glacial lakes as there is no basis available for calculating the depth or volume of lakes assigned to the other types. Instead, the angle of reach is set to $\omega_{\mathrm{r}}=11^{\circ}$ (the value suggested by Haeberli, 1983) for T1 and to $\omega_{\mathrm{r}}=14^{\circ}$ for T3.

The number of relationships T1-T4 (see Table 8) predicting an impact on a given raster cell determines the impact susceptibility: if all four relationships predict an impact, $I_{\mathrm{lo}}=6$, three relationships results in $I_{\mathrm{lo}}=5$ and so forth. For $I_{\mathrm{lo}}<6$, the run-up on the opposite slope is restricted. If only an impact as flood is predicted, (T4; $\left.I_{\mathrm{lo}} \leq 3\right)$, the impact susceptibility is further differentiated according to $\omega$ : for $\omega \geq 6$, $I_{\mathrm{lo}}=3$, for $\omega \geq 4, I_{\mathrm{lo}}=2$ and for $\omega \geq 2, I_{\mathrm{lo}}=1$. T4 is only applied to lakes $\geq 50000 \mathrm{~m}^{2}$. Furthermore, the criterion that 
Table 7. Scoring scheme for susceptibility to lake outburst triggered by internal factors $S_{\mathrm{lo}}$. The initial values of $S_{\mathrm{lo}}$ are determined from the dam material, these values are then increased or decreased according to lake drainage, lake evolution, downstream slope of dam, permafrost susceptibility and seismic susceptibility.

\begin{tabular}{llr}
\hline Criterion & Remarks & $S_{\mathrm{lo}, \mathrm{i}}$ \\
\hline \multirow{2}{*}{ Lake type (dam material) } & Erosion lake & 0 \\
& Block- or debris-dammed lake & 1 \\
& Glacial lake & 3 \\
\hline \multirow{2}{*}{ Lake drainage } & Permanent or temporary superficial drainage & -1 \\
& No recognizable superficial drainage & \pm 0 \\
\hline \multirow{2}{*}{ Lake evolution } & Stable or shrinking & \pm 0 \\
& Growing trend in either the period 1968-2002 or 2002-2009 & +1 \\
\hline \multirow{2}{*}{ Downstream slope of dam $\beta_{\mathrm{d}}$} & tan $\beta_{\mathrm{d}}<0.02$ & -1 \\
& tan $\beta_{\mathrm{d}} \geq 0.02$ & \pm 0 \\
\hline \multirow{2}{*}{ Permafrost susceptibility } & No permafrost or stable permafrost & \pm 0 \\
& Susceptible to melting at $\Delta$ MAAT $>0-4^{\circ}$ & +1 \\
\hline \multirow{2}{*}{ Seismic susceptibility } & PGA $<0.65 \mathrm{~g}$ & \pm 0 \\
& PGA $\geq 0.65 \mathrm{~g}$ & +1 \\
\hline
\end{tabular}

Table 8. Empirical relationships used for estimating the travel distance of lake outburst floods. GLOF - glacial lake outburst flood, $L$ - travel distance, $V_{\mathrm{d}}$ - debris flow volume, $\Delta Z$ - loss of elevation, $\omega_{\mathrm{r}}-$ average slope of reach, $Q_{\mathrm{p}}$ - peak discharge.

\begin{tabular}{llll}
\hline & Relationship & References & Remarks \\
\hline $\mathrm{T} 1$ & $L=1.9 V_{\mathrm{d}}^{0.16} \Delta Z^{0.83}$ & Rickenmann (1999) & for debris flows in general \\
\hline $\mathrm{T} 2$ & $\omega_{\mathrm{r}}=11^{\circ}$ & $\begin{array}{l}\text { Haeberli (1983), } \\
\text { Huggel et al. (2003, 2004a) }\end{array}$ & $\begin{array}{l}\text { for debris flows from GLOFs, applied } \\
\text { with } \omega_{\mathrm{r}}=8^{\circ} \text { in the present study } \\
\text { (Mergili and Schneider, 2011) }\end{array}$ \\
\hline $\mathrm{T} 3$ & $\omega_{\mathrm{r}}=18 Q_{\mathrm{p}}^{-0.07}$ & Huggel (2004) & worst case for debris flows from GLOFs \\
\hline $\mathrm{T} 4$ & $\omega_{\mathrm{r}} \geq 2^{\circ}$ & Haeberli (1983), & for floods from GLOFs \\
& & Huggel et al. (2004a) & \\
\hline
\end{tabular}

the distance from the source has to increase with each computing step is disabled for floods.

Analogously to the procedure applied to rock slides, ice avalanches and periglacial debris flows (see Sects. 4.2-4.4), the impact hazard indicator is derived by combining $I_{\text {lo }}$ with $H_{\text {lo }}$ of the corresponding lake (see Table 4). The global impact hazard indicator $\mathrm{IH}_{\mathrm{lo}}$ of a given raster cell is defined as the maximum of all lake-specific indicators (see Eq. 2).

\section{Results}

The total area with indication of a significant periglacial debris flow (PF) susceptibility/hazard is much larger than for the other hazard types: $9.9 \%$ of the entire study area is designated as a possible PF source area, based on the criteria defined in Table 6. Out of this area $42.7 \%$ is assigned the three higher susceptibility scores 4-6 (Fig. 7a). This pattern indicates the ubiquity of possibly hazardous areas on the one
Table 9. Empirical regression equations relating peak discharge $Q_{\mathrm{p}}$ of glacial lakes to outburst volume $V_{1}$ and lake depth (dam height) $D_{1} . \rho_{\mathrm{W}}-$ density of water $\left(\mathrm{kg} \mathrm{m}^{-2}\right), g-$ gravity $\left(\mathrm{m} \mathrm{s}^{-2}\right),{ }^{*}$ envelope (worst case).

\begin{tabular}{lll}
\hline Reference & & $Q_{\mathrm{p}}\left(\mathrm{m}^{3} \mathrm{~s}^{-1}\right)$ of glacial lakes \\
\hline Costa (1985) & $\mathrm{Q} 1$ & $113\left(10^{-6} V_{1}\right)^{0.61}$ \\
& $\mathrm{Q} 2$ & $3.8\left(10^{-6} V_{1} D_{1}\right)^{0.61}$ \\
\hline Costa and & $\mathrm{Q} 3$ & $1.3 \times 10^{-4}\left(\rho_{\mathrm{W}} g V_{1} D_{1}\right)^{0.60}$ \\
Schuster (1988) & $\mathrm{Q} 4$ & $5.5 \times 10^{-6}\left(\rho_{\mathrm{W}} g V_{1} D_{1}\right)^{0.59}$ \\
\hline Walder and & $\mathrm{Q}^{*}$ & $2.2 \times 10^{-1} V_{1}^{0.66}$ \\
O'Connor (1997) & $\mathrm{Q}^{*}$ & $1.1\left(V_{1} D_{1}\right)^{0.47}$ \\
\hline
\end{tabular}


hand, but also the limited means of a sharper delineation on the other hand. In contrast, the ice avalanche (IA) susceptibility and the lake outburst (LO) susceptibility, due to their confinement to glaciers and lakes, respectively, are constrained in a much sharper way. Of the total study area $1.6 \%$ is identified as susceptible to IA, $64.5 \%$ out of this area is assigned the susceptibility scores $4-6$ (see Fig. 7a). The LO susceptibility is discretized on the basis of lakes. $70.9 \%$ of all lakes are assigned susceptibility scores $>0,50.0 \%$ of these lakes the susceptibility scores 4-6 (see Fig. 7a). The rock slide (RS) susceptibility displays intermediate patterns in terms of the total area identified as susceptible ( $4.7 \%$ of the total study area). However, only $16.2 \%$ of this area - a much lower value than those associated with the other process types - is assigned the susceptibility scores 4-6 (see Fig. 7a). The reason for this phenomenon is the limited area occupied by very steep slopes (see Table 5).

The distribution of the raster cells or lakes identified as susceptible among the six hazard indicator classes is illustrated in Fig. 7b, depending on the susceptibility and the possible process magnitude (see Table 3). Of the RS $38.1 \%$ and of the IA $68.4 \%$ is assigned the hazard indicator classes 4-6. In the case of PF, hazard indicator and susceptibility are identical due to lacking means for an estimation of the magnitude (see Sect. 4.4). Comparatively few lakes (23.9\%) are assigned the LO hazard indicator classes 4-6. This phenomenon is explained by the large number of rather small but highly susceptible lakes.

Figure 8 represents the hazard indicators for each process type broken down to the level of small catchments identical to the output parameter basin of the GRASS GIS raster module r.watershed (GRASS Development Team, 2013) with a threshold parameter of 5000. The maximum out of all raster cell-based hazard indicators is shown for each catchment, except for the LO hazard indicator where the value assigned to each lake is illustrated.

As expected, the RS hazard indicator (see Fig. 8a) is highest in areas with a particularly steep topography in the northern and central Pamir. More localized possible high-hazard areas are distributed throughout the study area. The IA hazard indicator (see Fig. 8b) is high in most glacierized areas (see Fig. 3d), particularly in parts of the northern Pamir where large portions of steep glaciers are extremely abundant. Within these zones the inter-catchment differentiation of possibly hazardous areas is rather poor.

The PF hazard indicator is poorly differentiated at the catchment scale: steep slopes near the permafrost boundary are almost ubiquitous in the study area (see Fig. 3b), except for the elevated and comparatively gently inclined south-eastern portion. The most notable regional pattern is therefore attributed to the seismic susceptibility. The patterns observed in Fig. 8c are further a consequence of the limited input information that can be reasonably applied at the regional scale (see Table 6). A detailed inventory of rock glaciers (comparable to the inventories prepared for glaciers (a) Susceptibility indicator $S$

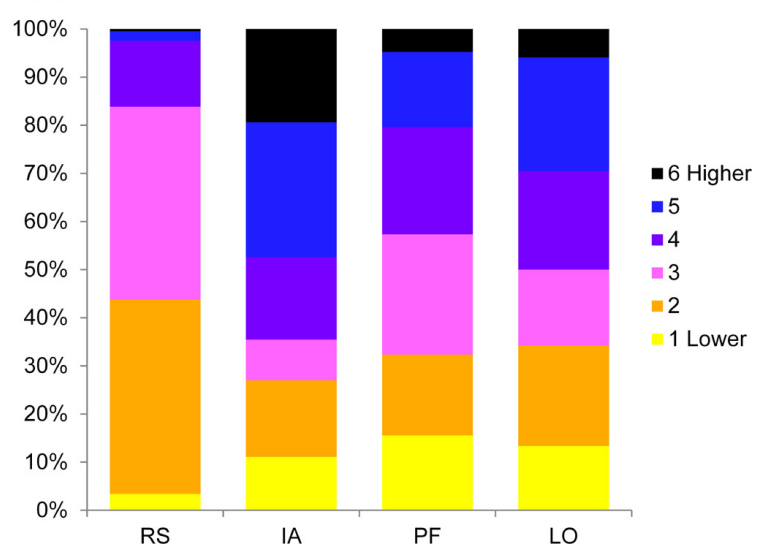

(b) Hazard indicator $H$

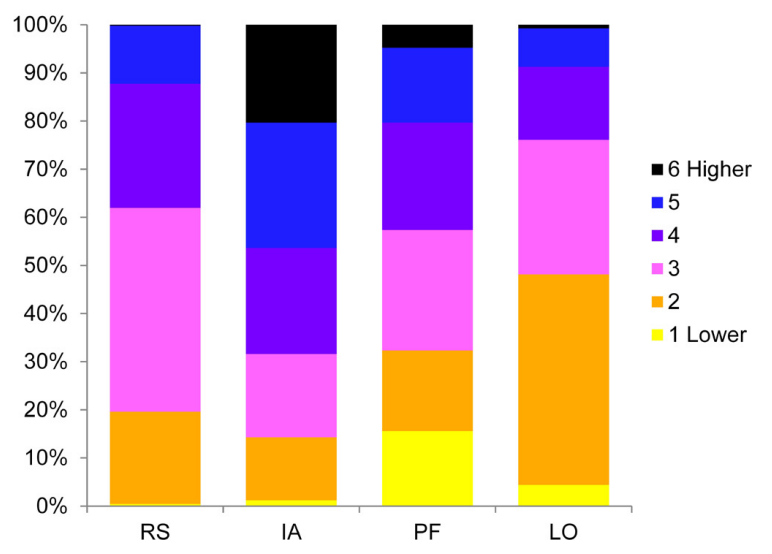

Fig. 7. Relative abundance of (a) the susceptibility and (b) the hazard indicator classes for the four considered processes. The indicators for rock slides (RS), ice avalanches (IA) and periglacial debris flows (PF) relate to raster cells, the indicators for lake outburst floods (LO) to lakes. Only those raster cells or lakes with an indicator of at least 1 are considered.

and lakes, see Fig. 3d) could help to sharpen the distinction between more and less hazardous areas. However, as rock glaciers are extremely common throughout the study area, the patterns at the inter-catchment level would most likely remain unchanged.

As the LO hazard indicator is directly related to the wellknown lake distribution it can be discretized at a high level of detail (see Fig. 8d). Nine lakes are assigned the highest LO hazard indicator class $H_{\mathrm{lo}}=6$, the largest of them is Lake Sarez. Even though - or because - the safety of Lake Sarez is highly disputed (e.g. Risley et al., 2006), this classification seems reasonable. The LO susceptibility score $S_{\mathrm{lo}}=5$ is a consequence of the high topographic susceptibility. The same is true for Lake Zardiv, with $0.7 \mathrm{~km}^{2}$ the second largest lake with $H_{\text {lo }}=6$ (see Fig. 8d). Further lakes of interest are, e.g. Lake Khavraz and Lake Shiva. Lake Khavraz is a $1.9 \mathrm{~km}^{2}$ lake impounded behind a rock glacier at an elevation of $4000 \mathrm{~m}$ a.s.l., in the zone of possibly melting permafrost. 

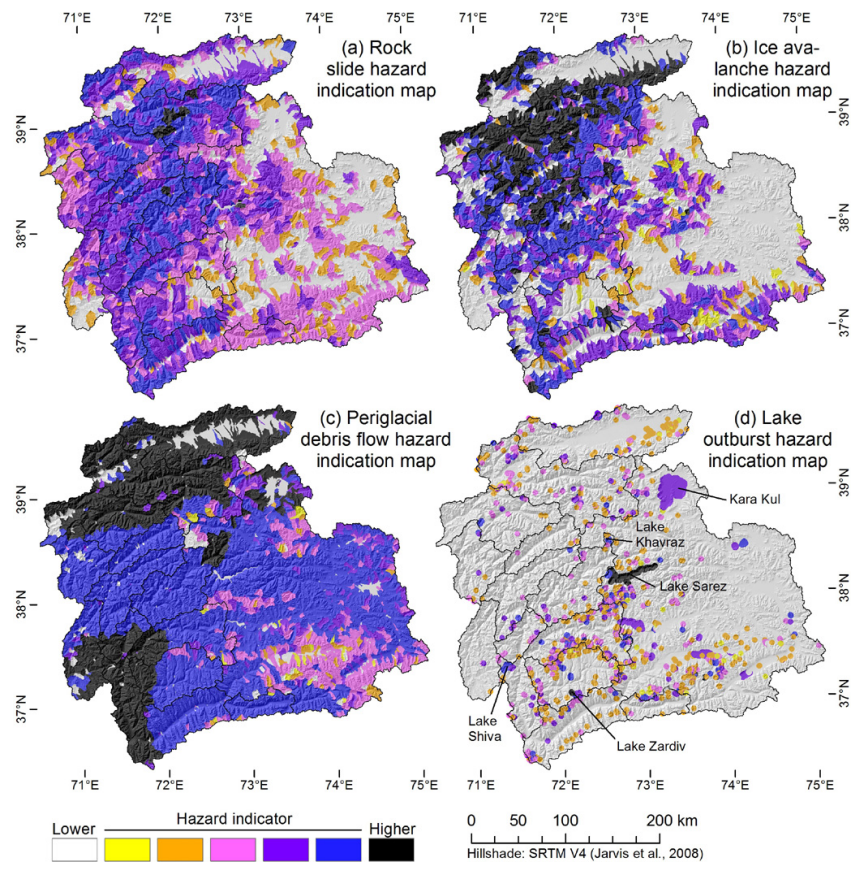

Fig. 8. Distribution of (a) rock slide, (b) ice avalanche, (c) periglacial debris flow and (d) lake outburst hazard indicators over the entire study area. The maximum indicator is shown for each catchment.

Here both the topographic susceptibility $\left(S_{\mathrm{lo}, \mathrm{e}}=5\right)$ and the LO susceptibility due to internal factors $\left(S_{\mathrm{lo}, \mathrm{i}}=5\right)$ are at high levels. Lake Shiva is assigned a susceptibility in the medium range of the scale $\left(S_{\mathrm{lo}}=3\right)$ and a sudden drainage is not likely but, due to the large size of $15.2 \mathrm{~km}^{2}, H_{\mathrm{lo}}=5$. The lake is located close to several communities in the Panj Valley which could be affected in the case of such an event. The largest lake in the study area, Karakul, is assigned the hazard indicator class 4 (see Fig. 8d). The LO susceptibility of Karakul is rated with a score of $S_{\mathrm{lo}}=2$, only the very large lake area $\left(405 \mathrm{~km}^{2}\right)$ leads to the relatively high hazard indicator. The fact that a closer look reveals no significant outburst hazard of Karakul suggests that the approach used tends to overestimate the hazard for large lakes. One reason for this phenomenon is the topographic susceptibility: large lakes usually have a larger capacity to alleviate the impact of mass movements than small lakes. However, an objective basis to include the dependence of the topographic susceptibility on lake size is missing. Table 10 summarizes the LO susceptibility and hazard indicator by lake type. Whilst - as prescribed by the scheme shown in Table 7 - glacial lakes clearly display the higher scores of the LO susceptibility due to internal factors, this tendency is less pronounced - but still visible - for the LO susceptibility due to external factors.

The median and maximum travel distances computed for each process type are summarized in Table 11. The RS model commonly predicts travel distances from $3.0 \mathrm{~km}$ (average) to $5.6 \mathrm{~km}$ (envelope), but for very large events $\left(>800 \times 10^{6} \mathrm{~m}^{3}\right)$

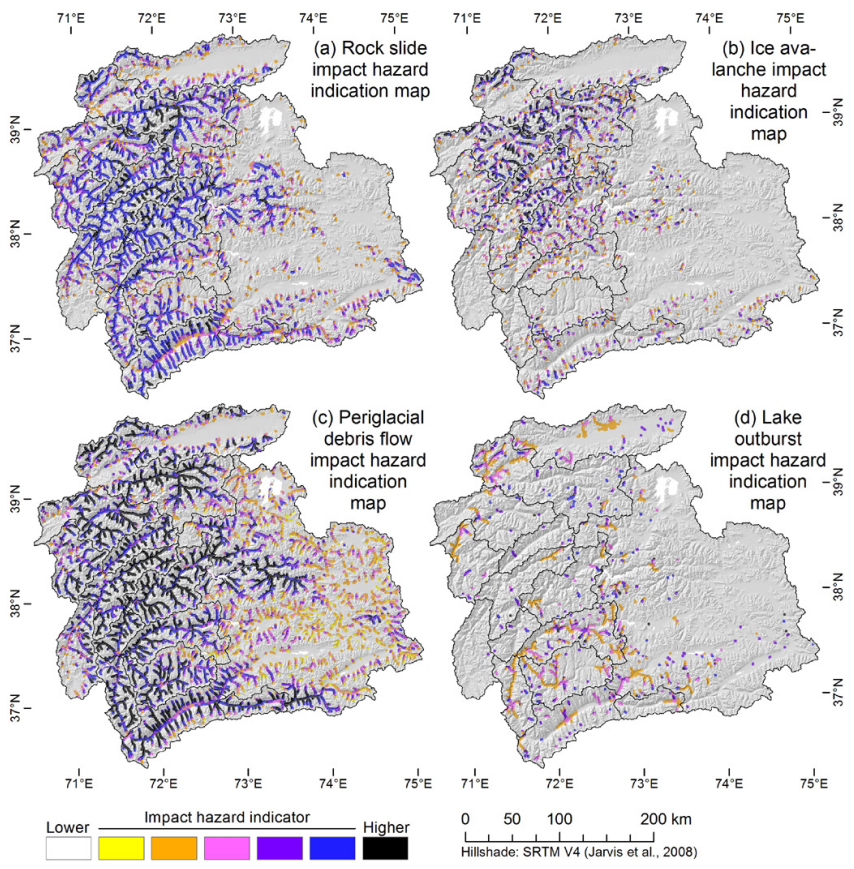

Fig. 9. Impact hazard indicator for each process, (a) rock slides, (b) ice avalanches, (c) periglacial debris flows, and (d) lake outburst floods. For clarity, only the indicators along the main flow lines are shown.

extending over vertical distances $>4000 \mathrm{~m}$ the model, when applied with the envelope, predicts a maximum travel distance of almost $50 \mathrm{~km}$ (see Eq. 4). The IA model $\left(\omega_{\mathrm{r}, \mathrm{E}}=17^{\circ}\right)$ and the PF model $\left(\omega_{\mathrm{r}, \mathrm{E}}=11^{\circ}\right)$ predict shorter travel distances. Note that, in both cases, the difference between the median and the maximum is only caused by topography and not by the assumed process magnitude. The LO model predicts the possibility of a significant debris flow for less than half of all lakes (no meaningful median value can therefore be given in Table 11). The reason for this phenomenon is mainly the gentle slope observed downstream from many lakes. However, lakes with steeper downstream slopes can produce debris flows with travel distances $>15 \mathrm{~km}$ and floods with travel distances $>80 \mathrm{~km}$, according to the model.

Figure 9 shows the distribution of the impact hazard indicator. For clarity, only the raster cell values along the main flow channels are shown. It is clear that the general patterns of the impact hazard indicator at the broad scale resemble those of the hazard indicator shown in Fig. 9: whilst a possible impact of rock slides and periglacial debris flows is shown for most valleys particularly in the western part of the study area (Fig. 9a, c), a more localized impact of ice avalanches and lake outburst floods is suggested by the model (Fig. 9b, d).

The distribution of the community risk indicator over the study area reflects the patterns shown in Figs. 8 and 9 on the one hand, and the distribution of the exposed communities on the other hand. Figure 10 illustrates the relative frequency 
Table 10. Percentage of lakes assigned to each lake outburst (LO) susceptibility (internal and external factors) and hazard indicator class according to lake type.

\begin{tabular}{|c|c|c|c|c|c|c|c|c|}
\hline \multirow[t]{2}{*}{ Lake type } & \multicolumn{8}{|c|}{ LO susceptibility class (internal factors) } \\
\hline & 0 & 1 & 2 & 3 & 4 & 5 & 6 & Sum \\
\hline Erosion lakes & $33.1 \%$ & $40.8 \%$ & $24.7 \%$ & $1.5 \%$ & $0.0 \%$ & $0.0 \%$ & $0.0 \%$ & 883 \\
\hline Block- or debris-dammed lakes & $12.4 \%$ & $17.1 \%$ & $44.8 \%$ & $24.8 \%$ & $1.0 \%$ & $0.0 \%$ & $0.0 \%$ & 105 \\
\hline \multirow[t]{3}{*}{ Glacial lakes } & $38.2 \%$ & $0.0 \%$ & $0.0 \%$ & $4.4 \%$ & $31.1 \%$ & $24.5 \%$ & $1.7 \%$ & 652 \\
\hline & \multicolumn{8}{|c|}{ LO susceptibility class (external factors) } \\
\hline & 0 & 1 & 2 & 3 & 4 & 5 & 6 & Sum \\
\hline Erosion lakes & $42.1 \%$ & $5.3 \%$ & $18.9 \%$ & $16.5 \%$ & $7.5 \%$ & $7.7 \%$ & $1.9 \%$ & 883 \\
\hline Block- or debris-dammed lakes & $18.1 \%$ & $1.0 \%$ & $10.5 \%$ & $14.3 \%$ & $18.1 \%$ & $32.4 \%$ & $5.7 \%$ & 105 \\
\hline \multirow[t]{3}{*}{ Glacial lakes } & $40.8 \%$ & $0.2 \%$ & $3.5 \%$ & $11.3 \%$ & $15.5 \%$ & $21.3 \%$ & $7.4 \%$ & 652 \\
\hline & \multicolumn{8}{|c|}{ LO hazard indicator class } \\
\hline & 0 & 1 & 2 & 3 & 4 & 5 & 6 & Sum \\
\hline Erosion lakes & $24.5 \%$ & $5.8 \%$ & $34.2 \%$ & $19.0 \%$ & $10.6 \%$ & $5.3 \%$ & $0.6 \%$ & 883 \\
\hline Block- or debris-dammed lakes & $12.4 \%$ & $0.0 \%$ & $31.4 \%$ & $23.8 \%$ & $13.3 \%$ & $16.2 \%$ & $2.9 \%$ & 105 \\
\hline Glacial lakes & $38.2 \%$ & $0.0 \%$ & $26.5 \%$ & $20.2 \%$ & $10.4 \%$ & $4.4 \%$ & $0.2 \%$ & 652 \\
\hline
\end{tabular}

Table 11. Maximum and median travel distances $L(\mathrm{~m})$ computed for each process. RS - rock slides, IA - ice avalanches, $\mathrm{PF}-$ periglacial debris flows, $\mathrm{LO}$ - lake outburst floods, A - average, Eenvelope, dfl-debris flow, fld-flood.

\begin{tabular}{lrrrrrr}
\hline & RS (A) & RS (E) & IA (E) & PF (E) & LO (dfl) & LO (fld) \\
\hline Maximum & 23867 & 49516 & 10735 & 15906 & 15597 & 81946 \\
Median & 2964 & 5628 & 2013 & 2618 & - & 12589 \\
\hline
\end{tabular}

of the community risk indicator classes for 15 regions within the study area, each of them representing a catchment or section of a catchment. The eastern Pamir is considered as one single region due to the low number of communities there. Except for the very western part of the study area, the eastern Pamir and the Kyrgyz part of the study area (Chan-Alai Valley) in the north, all regions are dominated by communities with indication of a significant rock slide risk, the highest scores are observed for the villages in the rugged Bartang and middle Panj valleys as well as in the Gunt Valley (see Fig. 10a). The hot spots of possible ice avalanche risk are identified in the Vanch and Bartang valleys, both deeply incised into glacierized mountain ranges (see Fig. 10b). This type of risk plays a less prominent role in the other regions. Also the risk indicator for periglacial debris flows is highest in the deep gorges of the western Pamir, decreasing towards the north where permafrost is less abundant (see Fig. 10c). However, the model yields a significant PF risk indicator for most communities throughout the study area. This is not the case for the risk indicator for lake outburst floods, which is highest mainly in the south-western Pamir and in part of the northern Pamir (see Fig. 10d). The LO community risk
Table 12. Per cent of communities assigned to each class of the community risk indication score. Abbreviations as in Table 11.

\begin{tabular}{|c|c|c|c|c|c|c|c|}
\hline \multirow{2}{*}{$\begin{array}{l}\text { Process } \\
\text { type }\end{array}$} & \multicolumn{7}{|c|}{ Community risk indication score } \\
\hline & 0 & 1 & 2 & 3 & 4 & 5 & 6 \\
\hline RS & $12.1 \%$ & $9.7 \%$ & $8.6 \%$ & $15.3 \%$ & $27.5 \%$ & $23.9 \%$ & $2.9 \%$ \\
\hline IA & $75.2 \%$ & $8.9 \%$ & $5.7 \%$ & $4.8 \%$ & $2.2 \%$ & $2.4 \%$ & $0.8 \%$ \\
\hline $\mathrm{PF}$ & $11.5 \%$ & $3.7 \%$ & $6.1 \%$ & $9.2 \%$ & $24.4 \%$ & $31.4 \%$ & $13.9 \%$ \\
\hline LO & $65.6 \%$ & $12.3 \%$ & $11.6 \%$ & $6.2 \%$ & $2.9 \%$ & $1.4 \%$ & $0.0 \%$ \\
\hline
\end{tabular}

indicator $\mathrm{CR}_{\text {lo }}=6$ is not assigned to any village. Table 12 summarizes the relative frequency of villages assigned to each class with respect to all four hazard types.

A composite hazard and risk indication map is prepared for the entire study area. It provides a visual overlay of the hazard, impact hazard and community-based risk indicators for each of the four process types considered in the study. Figure 11 shows this map for a selected area covering the Gunt Valley and its tributaries (see Fig. 2 for delineation). The area affected by the prehistoric Charthem rock slide (see Fig. 11a) is very well reproduced by the model, therefore a high RS risk indicator class is assigned to the nearby communities. However, also several other communities and lakes are possibly impacted by rock slides. The patterns of the IA hazard and risk indicators illustrate the isolated appearance of this type of hazard in the area (see Fig. 11b). Even though the main effect of the process is the possible impact on lakes, some communities in the main valley are possibly at risk, but assigned rather low risk indicator classes. Areas with a PF hazard indicator (see Fig. 11c) are confined to steep slopes near the permafrost boundary which are however 

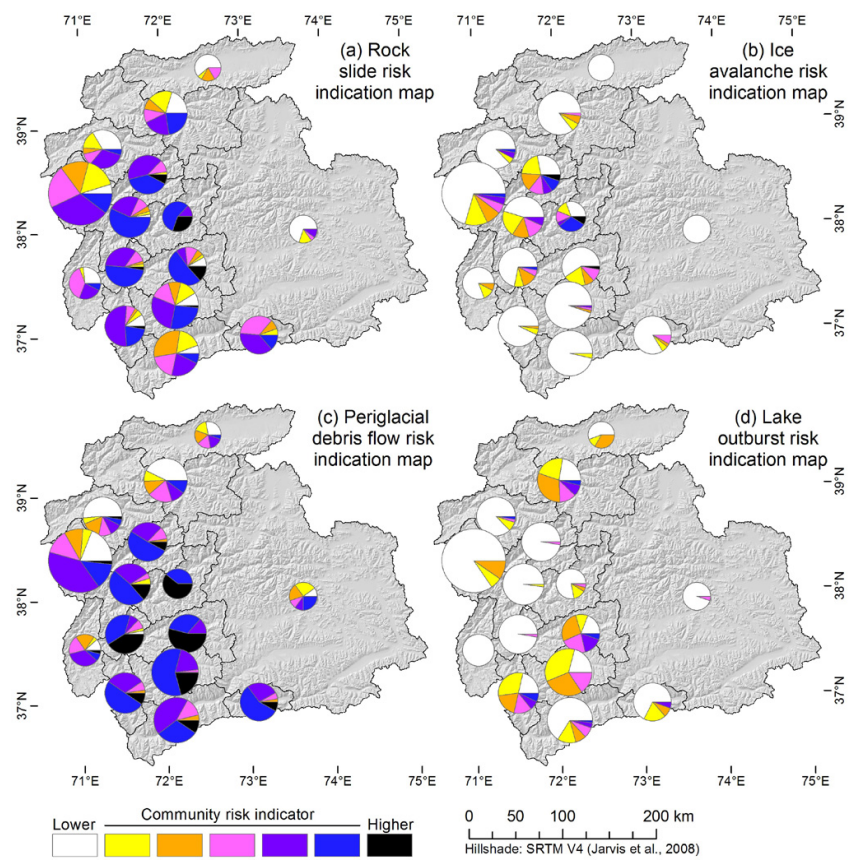

Fig. 10. Community risk indicators, generalized to 15 regions. For each region, the pie chart illustrates the relative abundance of the different community risk indicator classes. The size of each chart is proportional to the number of communities it represents.

very common along the slopes of most valleys, confirming the broad-scale patterns shown in Fig. 8c. Therefore, most of the communities in the valleys are identified as possibly at risk. The occurrence of periglacial debris flows in this area, often starting from the termini of rock glaciers, is evident in the field and from remotely sensed imagery (see Fig. 1c). The associated debris cones are located in zones displaying the higher impact hazard indicator classes. In contrast, many lakes are located in areas where permafrost is assumed stable.

Several lakes have developed near the termini of the glaciers of the tributary valleys (Mergili and Schneider, 2011; Mergili et al., 2013b). Three of them are assigned the hazard indicator class $H_{\mathrm{lo}}=5$ (see Fig. 11d). The debris flow travel distances predicted by the LO model are relatively short, only debris flows from two lakes could reach the communities of the main valley: the village of Varshedz is just located at the terminus of a possible debris flow starting from Lake Varshedz (see Fig. 1d; lake area $0.16 \mathrm{~km}^{2}, S_{\mathrm{lo}}=5$, $H_{\mathrm{lo}}=5$ ). Lake Nimats, an erosion lake with $S_{\mathrm{lo}}=4$ and $H_{\mathrm{lo}}=5$, drains into a very steep channel heading directly down to the main valley. In the case of a (not very likely) sudden drainage, the nearby villages would most likely suffer substantial damage. The impact area of the distal floods resulting from the possible drainage of Lake Varshedz or Lake Nimats is characterized by lower to medium community risk indicators of the possibly affected villages. The largest lake shown in Fig. $11 \mathrm{~d}$ is Rivakkul $\left(1.2 \mathrm{~km}^{2}, S_{\mathrm{lo}}=4, H_{\mathrm{lo}}=5\right)$. It
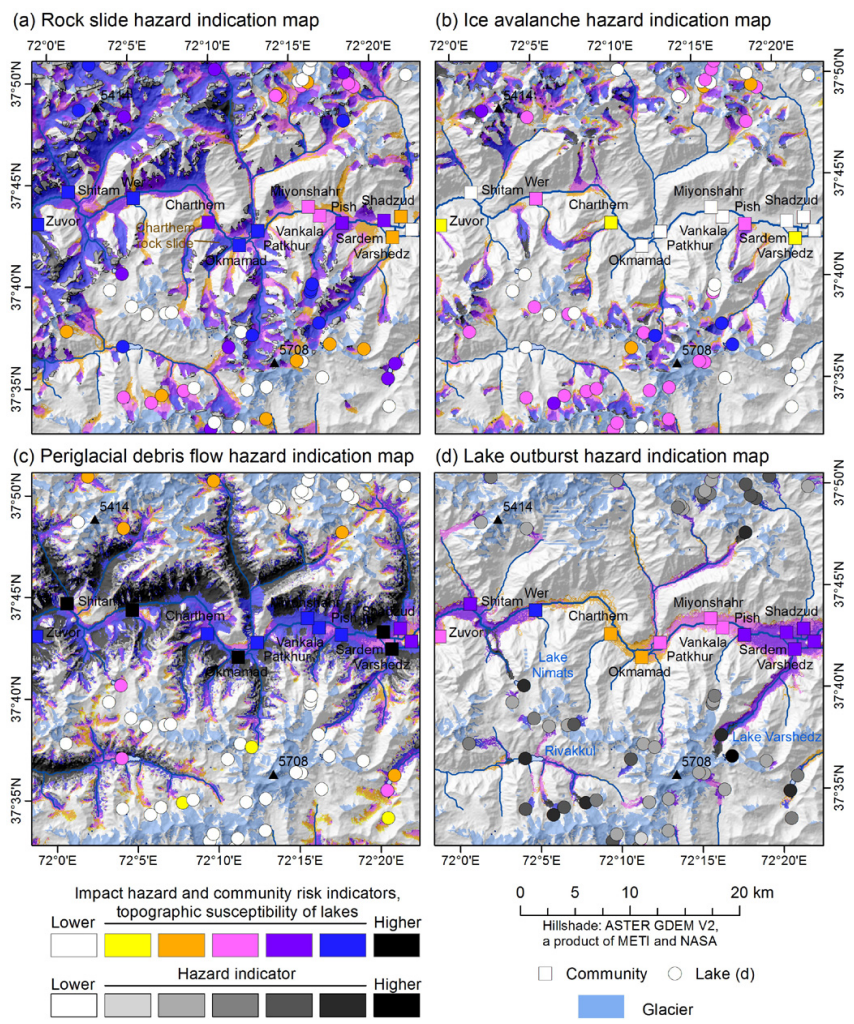

Fig. 11. Hazard indicator, impact hazard indicator, topographic susceptibility of lakes and community risk indicator associated with each process type. (a) Rock slide, (b) ice avalanche, (c) periglacial debris flow, and (d) lake outburst flood. The extent of the map is shown in Fig. 2.

is characterized by a very gently inclined downstream valley. As a result, the model predicts only a comparatively short travel distance of a possible outburst flood $(4.6 \mathrm{~km})$, being alleviated far upslope from the villages in the main valley.

\section{Discussion}

The purpose of the model approach introduced in the previous sections and the resulting hazard and risk indication maps is to provide a reproducible basis for targeted hazard and risk assessment studies and mitigation measures at the community scale. The approach chosen is thought to be useful for the study area in the Pamir for two reasons.

First, the general difficulty of establishing frequencies for rare or singular events in combination with sparse historical data in the study area makes strictly quantitative approaches such as statistical methods inapplicable. Therefore a hazard and risk indication scoring scheme has to be applied, even though such a concept introduces a certain degree of subjectivity. 
Second, the vulnerability of the local population to these types of hazards is high, even though NGOs have launched programs to improve the awareness of and the preparedness for geohazard events in the previous decade. This situation is comparable to other high-mountain areas in developing countries (e.g. Carey, 2005). The results of the present study shall highlight possible high-risk areas and serve as a baseline for in-detail studies and risk mitigation procedures.

Consequently, the outcome of the study should not be seen as definite hazard and risk maps, but rather as conceptual hazard and risk indication maps. The hazard and risk indicator classes are therefore not given definite names such as moderate hazard, extremely high risk, etc. Further, the interpretation of the model results on the basis of raster cells is appropriate for scientific discussion, but not for the design of risk mitigation measures. Here the scale of communities (see Fig. 11), catchments (see Fig. 9) or even regions (see Fig. 10) are much more suitable.

As far as a comparison with observed events is possible, it confirms the model results (e.g. Charthem rock slide, see Fig. 11a). In the case of large rock slides such as the 1911 Sarez event (see Fig. 1a) the comparison with the model results is of limited value due to the substantial change of the topography caused by such events. No records of ice avalanches in the study area are known to the authors whilst geomorphic evidence indicates that periglacial debris flows are common. Their source and impact areas are well recognized by the model, but the false positive rate is high. The two lakes with recorded sudden drainage are not characterized by exceptionally high susceptibility scores - the prediction of lake outburst floods is therefore particularly challenging.

The quality of the model results strongly depends on the input data used. The detail and accuracy of the ASTER GDEM is considered sufficient for the purpose of the present study, even though the quality of the dam geometry estimates may suffer from artefacts and inaccuracies known for this type of DEM. Also the quality of the carefully mapped lake, glacier and land use data sets is largely considered sufficient. The potential permafrost areas were determined using a rule-of-thumb approach, adapting data obtained in the Alps (Haeberli, 1975; Mergili et al., 2012a). Even though the predicted conditions and scenarios are likely to be realistic, uncertainties are hard to quantify. The seismic hazard map used (Giardini et al., 1999) is a highly generalized global data set. Other essential information such as the distinction bedrock residual rock or the orientation and dip of the bedding planes of geological layers are hard to manage at the scale relevant for a study of this type.

The scoring schemes used (see Tables 2-7) are founded on expert knowledge. The interpretation of the model results have to consider the characteristics of the scheme used for each process. Necessarily, the schemes contain \pm arbitrary thresholds such as those used for the event magnitude (see Table 3 ) or the $45^{\circ}$ minimum slope for rock slides already used earlier by Hergarten (2012).
The modelling of the travel distance and the impact area of the considered processes is derived from the statistics of observed events. These statistics are reasonably robust for rock slides and rock ice avalanches (Scheidegger, 1973; Evans and Clague, 1988; Bottino et al., 2002; Noetzli et al., 2006) and also for ice avalanches (Huggel et al., 2004a). However, they are based on observations from other mountain areas such as the Alps. Their application is based on the hypothesis that (i) the patterns observed there are comparable to those in the Pamir and (ii) that the - often rather small - data sets used for the derivation of the patterns and thresholds cover a representative sample of the reality. This is equally true for the slope-temperature curve shown in Fig. 6. The situation is even more difficult for periglacial debris flows (Huggel et al., 2004a) and particularly for lake outburst floods. The threshold of $\omega_{\mathrm{r}, \mathrm{E}}=11^{\circ}$ used by Huggel et al. (2004a, b) for debris flows from lake outburst events is not applicable to the Pamir as the 2002 Dasht event, where $\omega_{\mathrm{r}, \mathrm{E}} \sim 9.3^{\circ}$, has shown (Mergili and Schneider, 2011). Also the parameterization of floods developing from lake outburst events is nothing more than a rough estimate so that the results (such as the short travel distance predicted for a sudden drainage of Rivakkul, see Fig. 11d) have to be interpreted with utmost care.

Further, the application of average slopes neglects the loss of energy due to changes of the flow direction. Strictly spoken, such concepts should only be used for straight flow paths. The criterion that the motion has to move away from the source with each step of the random walk partly accounts for this limitation.

Possible impact waves due to mass movements into lakes are explicitly accounted for by the model. Other types of interactions are included indirectly: the conversion of rock slides into rock-ice avalanches by the impact on glaciers is implicitly considered in the rock slide model, even though there are no means to estimate the entrainment of snow or ice. Furthermore, the empirical relationships used partly include process chains such as the conversion into a debris flow. Some process interactions are out of scope of the present study, such as the damming of lakes by mass movements and possible subsequent drainage. The same is true for the entrainment of debris, modelling of which remains a challenge particularly at the scale of the present study.

An aspect explicitly excluded from the present work pertains to roads and other types of linear structures. The cell size of $60 \mathrm{~m} \times 60 \mathrm{~m}$ used does not allow us to consider the road network within the communities and imposes some methodological challenges on determining risk indicators for the overland roads or power lines. Further, a considerable amount of additional work would be necessary to define appropriate sections of the linear structures and to assign an appropriate exposure class to each section in order to discretize the risk indicators in a way comparable to the villages. For these reasons we consider linear structures out of the scope of the present work, but as an important topic for possible future work. 
Further, the approach used does not allow for an analytical overlay of the susceptibility, hazard, impact hazard and risk indicators associated to each process type. Even though attempted as far as possible, a homogenization of the scoring schemes for the different processes proves highly problematic due to the missing physical basis. The data the analysis is based on differs between the processes: e.g. the possible magnitude of rock slides is given in maximum volumes whilst only the maximum involved surface area allowed under the assumptions taken is used for possible ice avalanches and lake outburst floods (see Table 3). Also the schemes for susceptibility can hardly be homogenized (see Tables 5-7; Fig. 6), partly due to the varying level of detail of the available input data.

\section{Conclusions}

A regional-scale multi-hazard and -risk indicator model was introduced, including four selected high-mountain processes: (i) rock slides and rock avalanches, (ii) ice avalanches, (iii) periglacial debris flows and (iv) lake outburst floods. The model results for a very large area centred in the Pamir (Tajikistan) were presented and discussed. The model shall help to distinguish areas with higher hazard and risk from those with lower hazard and risk, even though the possibilities for comparison with observed events are limited. The interpretation of the model results - preferably at the level of communities, catchments or regions - has to take into account the characteristics of the scoring schemes as well as the limitations of the input data and the methodology used.

Acknowledgements. The work presented is part of the project PAMIR supported by the European Commission (EC) and the Austrian Development Agency (ADA), as well as of the project TajHaz supported by FOCUS Humanitarian Assistance (an affiliate of the Aga Khan Development Network), the Swiss Agency for Development and Cooperation (SDC) and the UK Department for International Development (DFID). The Tajik Agency of Hydrometeorology has provided meteorological data. Special thanks for their support go to Matthias Benedikt, Johannes P. Müller and Jean F. Schneider, BOKU University, Vienna. Finally, we acknowledge the extremely useful comments provided by Thomas Glade, University of Vienna, and by the two anonymous reviewers.

Edited by: M. Parise

Reviewed by: two anonymous referees

\section{References}

Alean, J.: Ice avalanches: some empirical information about their formation and reach, J. Glaciol., 31, 324-333, 1985.

Beniston, M.: Climatic Change in Mountain Regions: A Review of Possible Impacts, Clim. Change, 59, 5-31, doi:10.1023/A:1024458411589, 2003.
Bolch, T., Peters, J., Yegorov, A., Prafhan, B., Buchroithner, M., and Blagoveshchensky, V.: Identification of potentially dangerous glacial lakes in the northern Tien Shan, Nat. Hazards, 59, 1691-1714, doi:10.1007/s11069-011-9860-2, 2011.

Bottino, G., Chiarle, M., Joly, A., and Mortara, G.: Modelling Rock Avalanches and Their Relation To Permafrost Degradation in Glacial Environments. Permafrost Periglac., 13, 283-288, doi:10.1002/ppp.432, 2002.

Breien, H., DeBlasio, F. V., Elverhoi, A., and Hoeg, K.: Erosion and morphology of a debris flow caused by a glacial lake outburst flood, Western Norway, Landslides, 5, 271-280, doi:10.1007/s10346-008-0118-3, 2008.

Carey, M.: Living and dying with glaciers: people's historical vulnerability to avalanches and outburst floods in Peru, Global Planet. Change, 47, 122-134, doi:10.1016/j.gloplacha.2004.10.007, 2005.

Cenderelli, D. A. and Wohl, E. E.: Peak discharge estimates of glacial lake outburst floods and "normal" climatic floods in Mount Everest region, Nepal, Geomorphology, 40, 57-90, doi:10.1016/S0169-555X(01)00037-X, 2001.

Clarke, G. K. C.: Glacier outburst floods from "Hazard Lake", Yukon Territory, and the problem of flood magnitude prediction, J. Glaciol., 28, 3-21, 1982.

Corominas, J., Copons, R., Vilaplana, J. M., Altamir, J., and Amigó, J.: Integrated Landslide Susceptibility Analysis and Hazard Assessment in the Principality of Andorra, Nat. Hazards, 30, 421435, doi:10.1023/B:NHAZ.0000007094.74878.d3, 2003.

Costa, J. E.: Floods from Dam Failures, Denver, Colorado, U.S. Geol. Surv. Open File Rep. 85-560, 54 pp., 1985.

Costa, J. E. and Schuster, R. L.: The formation and failure of natural dams, Geol. Soc. Am. Bull., 100, 1054-1068, doi:10.1130/00167606(1988)100<1054:TFAFON>2.3.CO;2, 1988.

Dussaillant, A., Benito, G., Buytaert, W., Carling, P., Meier, C., and Espinoza, F.: Repeated glacial-lake outburst floods in Patagonia: an increasing hazard?, Nat. Hazards, 54, 469-481, doi:10.1007/s11069-009-9479-8, 2010.

Evans, S. G.: The maximum discharge of outburst floods caused by the breaching of man-made and natural dams, Can. Geotech. J., 23, 385-387, doi:10.1139/t86-053, 1986.

Evans, S. G. and Clague, J. J.: Catastrophic rock avalanchesin glacial environments, in: Landslides, edited by: Bonnard, C., A.A. Balkema, Rotterdam, 2, 1153-1158, 1988.

Evans, S. G. and Clague, J. J.: Recent climatic change and catastrophic geomorphic processes in mountain environments, Geomorphology, 10, 107-128, doi:10.1016/0169-555X(94)90011-6, 1994.

Evans, S. G., Bishop, N. F., Fidel Smoll, L., Valderrama Murillo, P., Delaney, K. B., and Oliver-Smith, A: A reexamination of the mechanism and human impact of catastrophic mass flows originating on Nevado Huascarán, Cordillera Blanca, Peru in 1962 and 1970, Eng. Geol., 108, 96-118, doi:10.1016/j.enggeo.2009.06.020, 2009a.

Evans, S. G., Roberts, N. J., Ischuk, A., Delaney, K. B., Morozova, G. S., and Tutubalina, O.: Landslides triggered by the 1949 Khait earthquake, Tajikistan, and associated loss of life, Eng. Geol., 109, 195-212, doi:10.1016/j.enggeo.2009.08.007, 2009b.

Giardini, D., Grünthal, G., Shedlock, K., and Zhang, P.: The GSHAP Global Seismic Hazard Map, Ann. Geophys., 42, 6 pp., doi:10.4401/ag-3784, 1999. 
GRASS Development Team: Geographic Resources Analysis Support System (GRASS) Software, Open Source Geospatial Foundation Project, available at: http://grass.osgeo.org(last access: 19 April 2013), 2013.

Haeberli, W.: Untersuchungen zur Verbreitung von Permafrost zwischen Flüelapass und Piz Grialetsch (Graubünden), Dissertation, University of Basel, Switzerland, 1975 (in German).

Haeberli, W.: Frequency and characteristics of glacier floods in the Swiss Alps, Ann. Glaciol., 4, 85-90, 1983.

Haeberli, W., Clague, J. J., Huggel, C., and Kääb, A.: Hazards from lakes in high-mountain glacier and permafrost regions: Climate change effects and process interactions, in: Avances de la Geomorphología en España, 2008-2010, edited by: Úbeda, X., Vericat, D., and Batalla, R. J., XI Reunión Nacional de Geomorphología, Solsona, Spain, 439-446, 2010a.

Haeberli, W., Portocarrero, C., and Evans, S.: Nevado Hualcán, Laguna 513 y Carhuaz 2010 - Observaciones, evaluación y recomendaciones (un corto informe técnico luego de las reuniones y visita de campo en Julio 2010), unpublished report on behalf of the Communidad Provincial de Carhuaz, 2010b (in Spanish).

Haritashya, U. K., Bishop, M. P., Shroder, J. F., Bush, A. B. G., and Bulley, H. N. N.: Space-based assessment of glacier fluctuations in the Wakhan Pamir, Afghanistan, Climatic Change, 94, 5-18, doi:10.1007/s10584-009-9555-9, 2009.

Harris, C., Arenson, L. U., Christiansen, H. H., Etzelmüller, B., Frauenfelder, R., Gruber, S., Haeberli, W., Hauck, C., Hölzle, M., Humlum, O., Isaksen, K., Kääb, A., Kern-Lütschg, M. A., Lehning, M., Matsuoka, N., Murton, J. B., Nötzli, J., Phillips, M., Ross, N., Seppälä, M., Springman, S. M., and VonderMühll, D.: Permafrost and climate in Europe: Monitoring and modelling thermal, geomorphological and geotechnical responses, EarthSci. Rev., 92, 117-171, doi:10.1016/j.earscirev.2008.12.002, 2009.

Harrison, S., Glasser, N., Winchester, V., Haresign, E., Warren, C., and Jansson, K.: A glacial lake outburst flood associated with recent mountain glacier retreat, Patagonian Andes, Holocene, 16, 611-620, doi:10.1191/0959683606h1957rr, 2006.

Hergarten, S.: Topography-based modelling of large rockfalls and application to hazard assessment, Geophys. Res. Lett., 39, L13402, doi:10.1029/2012GL052090, 2012.

Hewitt, K.: Natural dams and outburst floods in the Karakorum Himalaya, in: Hydrological aspects of alpine and high-mountain areas, edited by: Glen, J. W., IAHS Publication, 138, 259-269, 1982.

Hewitt, K. and Liu, J.: Ice-dammed lakes and outburst floods, Karakoram Himalaya: historical perspectives on emerging threats, Phys. Geogr., 31, 528-551, doi:10.2747/02723646.31.6.528, 2010.

Hewitt, K., Clague, J. J., and Orwin, J. F.: Legacies of catastrophic rock slope failures in mountain landscapes, Earth-Sci. Rev., 87, 1-38, doi:10.1016/j.earscirev.2007.10.002, 2008.

Huber, U., Bugmann, H., and Reasoner, M. (Eds.): Global Change and Mountain Regions. An overview of current knowledge, in: Advances in Global Change Research, Vol. 23, Springer, Dordrecht, 2005.

Huggel, C.: Assessment of Glacial Hazards based on Remote Sensing and GIS Modeling, Dissertation, University of Zurich, Schriftenreihe Physische Geographie Glaziologie und Geomorphodynamik, 2004.
Huggel, C., Kääb, A., Haeberli, W., Teysseire, P., and Paul, F.: Remote sensing based assessment of hazards from glacier lake outbursts: a case study in the Swiss Alps, Can. Geotech. J., 39, 316330, doi:10.1139/t01-099, 2002.

Huggel, C., Kääb, A., Haeberli, W., and Krummenacher, B.: Regional-scale GIS-models for assessment of hazards from glacier lake outbursts: evaluation and application in the Swiss Alps, Nat. Hazards Earth Syst. Sci., 3, 647-662, doi:10.5194/nhess-3-647-2003, 2003.

Huggel, C., Haeberli, W., Kääb, A., Bieri, D., and Richardson, S.: An assessment procedure for glacial hazards in the Swiss Alps, Can. Geotech. J., 41, 1068-1083, doi:10.1139/t04-053, 2004a.

Huggel, C., Kääb, A., and Salzmann, N.: GIS-based modeling of glacial hazards and their interactions using Landsat-TM and IKONOS imagery, Norwegian Journal of Geography, 58, 761773, doi:10.1080/00291950410002296, 2004b.

Huggel, C., Zgraggen-Oswald, S., Haeberli, W., Kääb, A., Polkvoj, A., Galushkin, I., and Evans, S. G.: The 2002 rock/ice avalanche at Kolka/Karmadon, Russian Caucasus: assessment of extraordinary avalanche formation and mobility, and application of QuickBird satellite imagery, Nat. Hazards Earth Syst. Sci., 5, 173-187, doi:10.5194/nhess-5-173-2005, 2005.

ICIMOD: Glacial lakes and glacial lake outburst floods in Nepal, ICIMOD, Kathmandu, 2011.

IPCC: Climate Change 2007: The Physical Science Basis, in: Contribution of Working Group I to the Fourth Assessment Report of the Intergovernmental Panel on Climate Change, edited by: Solomon, S., Qin, D., Manning, M., Chen, Z., Marquis, M., Averyt, K. B., Tignor, M., and Miller, H. L., Cambridge University Press, Cambridge and New York, 2007.

Iverson, R. M.: The physics of debris flows, Rev. Geophys., 35, 245-296, doi:10.1029/97RG00426, 1997.

Jarvis, A., Reuter, H. I., Nelson, A., and Guevara, E.: Hole-filled seamless SRTM data V4. International Centre for Tropical Agriculture (CIAT), available at: http://srtm.csi.cgiar.org, last access: 19 April 2013, 2008.

Kääb, A., Huggel, C., Fischer, L., Guex, S., Paul, F., Roer, I., Salzmann, N., Schlaefli, S., Schmutz, K., Schneider, D., Strozzi, T., and Weidmann, Y.: Remote sensing of glacier- and permafrostrelated hazards in high mountains: an overview, Nat. Hazards Earth Syst. Sci., 5, 527-554, doi:10.5194/nhess-5-527-2005, 2005.

Kassam, K. A.: Viewing Change Through the Prism of Indigenous Human Ecology: Findings from the Afghan and Tajik Pamir, Hum. Ecol., 37, 677-690, doi:10.1007/s10745-009-92848, 2009

Khromova, T. E., Osipova, G. B., Tsvetkov, D. G., Dyurgerov, M. B., and Barry, R. G.: Changes in glacier extent in the eastern Pamir, Central Asia, determined from historical data and ASTER imagery, Remote Sens. Environ., 102, 24-32, doi:10.1016/j.rse.2006.01.019, 2006.

Mahmood, S. A., Shahzad, F., and Gloaguen, R.: Remote Sensing Analysis of Recent Active Tectonics in Pamir Using Digital Elevation Model: River Profile Approach, in: Proceedings of the Geoscience and Remote Sensing Symposium IGARSS, 7-11 July 2008, II-1259-II-1262, 2008.

Makhmadaliev, B., Kayumov, A., Novikov, V., Mustaeva, N., and Rajabov, I. (Eds.): The Second National Communication of the Republic of Tajikistan under the United Nations Framework 
Convention on Climate Change, State Agency for Hydrometeorology, Dushanbe, 2008.

Mergili, M. and Schneider, J. F.: Regional-scale analysis of lake outburst hazards in the southwestern Pamir, Tajikistan, based on remote sensing and GIS, Nat. Hazards Earth Syst. Sci., 11, 14471462, doi:10.5194/nhess-11-1447-2011, 2011.

Mergili, M., Kopf, C., Müllebner, B., and Schneider, J. F.: Changes of the cryosphere in the high-mountain areas of Tajikistan and Austria: a comparison, Geogr. Ann. A, 94, 79-96, doi:10.1111/j.1468-0459.2011.00450.x, 2012a.

Mergili, M., Fellin, W., Moreiras, S. M., and Stötter, J.: Simulation of debris flows in the Central Andes based on Open Source GIS: Possibilities, limitations, and parameter sensitivity, Nat. Hazards, 61, 1051-1081, doi:10.1007/s11069-011-9965-7, 2012b.

Mergili, M., Schratz, K., Ostermann, A., and Fellin, W.: Physicallybased modelling of granular flows with Open Source GIS, Nat. Hazards Earth Syst. Sci., 12, 187-200, doi:10.5194/nhess-12187-2012, 2012c.

Mergili, M., Marchesini, I., Rossi, M., Guzzetti, F., and Fellin, W.: Spatially distributed three-dimensional slope stability modelling in a raster GIS, Geomorphology, doi:10.1016/j.geomorph.2013.10.008, in press, 2013a.

Mergili, M., Müller, J. P., and Schneider, J. F.: Spatio-temporal development of high-mountain lakes in the headwaters of the Amu Darya river (Central Asia), Global Planet. Change, 107, 13-24, doi:10.1016/j.gloplacha.2013.04.001, 2013b.

Müllebner, B.: Modelling of potential permafrost areas in the Pamir and Alai mountains (Tajikistan) using Remote Sensing and GIS techniques, Master thesis, BOKU University, Vienna, 2010.

Narama, C., Duishonakunov, M., Kääb, A., Daiyrov, M., and Abdrakhmatov, K.: The 24 July 2008 outburst flood at the western Zyndan glacier lake and recent regional changes in glacier lakes of the Teskey Ala-Too range, Tien Shan, Kyrgyzstan, Nat. Hazards Earth Syst. Sci., 10, 647-659, doi:10.5194/nhess-10-6472010, 2010.

Neteler, M. and Mitasova, H.: Open source GIS: a GRASS GIS approach, Springer, New York, 2007.

Noetzli, J., Huggel, C., Hoelzle, M., and Haeberli, W.: GIS-based modelling of rock-ice avalanches from Alpine permafrost areas, Computat. Geosci., 10, 161-178, doi:10.1007/s10596-005-9017z, 2006.

Quincey, D. J., Richardson, S. D., Luckman, A., Lucas, R. M., Reynolds, J. M., Hambrey, M. J., and Glasser, N. F.: Early recognition of glacial lake hazards in the Himalaya using remote sensing datasets, Global Planet. Change, 56, 137-152, doi:10.1016/j.gloplacha.2006.07.013, 2007.
Risley, J. C., Walder, J. S., and Denlinger, R.: Usoi dam wave overtopping and flood routing in the Bartang and Panj rivers, Tajikistan, Nat. Hazards, 38, 375-390, doi:10.1007/s11069-0051923-9, 2006.

Richardson, S. D. and Reynolds, J. M.: An overview of glacial hazards in the Himalayas, Quatern. Int., 65/66, 31-47, doi:10.1016/S1040-6182(99)00035-X, 2000.

Rickenmann, D.: Empirical Relationships for Debris Flows, Nat. Hazards, 19, 47-77, doi:10.1023/A:1008064220727, 1999.

Scheidegger, A. E.: On the Prediction of the Reach and Velocity of Catastrophic Landslides, Rock Mech., 5, 231-236, doi:10.1007/BF01301796, 1973.

Schuster, R. L. and Alford, D.: Usoi Landslide Dam and Lake Sarez, Pamir Mountains, Tajikistan, Environ. Eng. Geosci., 10, 151168, doi:10.2113/10.2.151, 2004.

Tinti, S., Maramai, A., and Cerutti, A. V.: The Miage Glacier in the Valley of Aosta (Western Alps, Italy) and the extraordinary detachment which occurred on 9 August 1996, Phys. Chem. Earth Pt. A, 24, 157-161, doi:10.1016/S1464-1895(99)00012-5, 1999.

Tweed, F. S. and Russell, A. J.: Controls on the formation and sudden drainage of glacier-impounded lakes: implications for jökulhlaup characteristics, Prog. Phys. Geog., 23, 79-110, doi:10.1177/030913339902300104, 1999.

Vilímek, V., Zapata, M. L., Klimes, J., Patzelt, Z., and Santillán, N.: Influence of glacial retreat on natural hazards of the Palcacocha Lake area, Peru, Landslides, 2, 107-115, doi:10.1007/s10346005-0052-6, 2005.

Walder, J. S. and Costa, J. E.: Outburst floods from glacierdammed lakes: the effect of mode of lake drainage on flood magnitude, Earth Surf. Proc. Land., 21, 701-723, doi:10.1002/(SICI)10969837(199608)21:8<701::AID-ESP615>3.0.CO;2-2, 1996.

Walder, J. S. and O'Connor, J. E.: Methods for Predicting Peak Discharge of Floods Caused by Failure of Natural and Constructed Earth Dams, Water Resour. Res., 33, 2337-2348, doi:10.1029/97WR01616, 1997.

Watanabe, T. and Rothacher, D.: The 1994 Lugge Tsho glacial lake outburst flood, Bhutan Himalaya, Mt. Res. Dev., 16, 77-81, 1996.

WGMS: Global Glacier Changes: Facts and Figures, edited by: Zemp, M., Roer, I., Kääb, A., Hoelzle, M., Paul, F., and Haeberli, W.: UNEP, World Glacier Monitoring Service, University of Zurich, Switzerland, available at: WGMS and UNEP websites: http://www.geo.uzh.ch/microsite/wgms/ (last access: 19 April 2013) and http://www.grid.unep.ch/glaciers/ (last access: 19 April 2013), 2008. 